\title{
NOTE
}

\section{PROOF OF THE CORPUS DELICTI ALIUNDE THE DEFENDANT'S CONFESSION}

Analytically, proof of the commission of a crime can be divided into three elements, each of which must be proved beyond a reasonable doubt: (1) the basic injury, such as the death in murder, the burning in arson, the missing property in theft, or the intercourse in rape, (2) the fact that the basic injury was the result of a criminal, rather than a natural or accidental, cause, and (3) the identification of the defendant as the perpetrator of the crime. $^{1}$ The first two of these elements constitute the corpus delicti or body of the crime, ${ }^{2}$ which is proved when the prosecution has shown that a crime has been committed by someone as, for example, where there is evidence that a body has been found and that death has been caused by a bullet wound in the back. Most jurisdictions in the United States hold that the defendant's confession alone is not sufficient proof of the corpus delicti and, therefore, that there must be proof, independent of the confession, that a crime was committed.

\section{Historical DeVelopMENT}

\section{In England}

Originally in England the defendant's confession was sufficient by itself to support a conviction. But in a few cases in which no body was found and conviction was based solely on a confession, the courts experienced the shock of having the person who had been thought dead turn up alive after his supposed murderer had been executed. In a seventeenth century prosecution ${ }^{3}$ it was shown that, when the defendant's master failed to return home one evening, the defendant was sent by the mistress of the house to look for the missing man and, when the defendant himself did not return, the master's son was sent to look for both. He succeeded in finding the servant, and together they questioned a woman who had found a hat which apparently belonged to the missing man. The hat, which was hacked and bloody, led them to believe that the master had been murdered. However, a search for the body proved unfruitful. Suspicion was directed toward the defendant, since he had not returned when sent to look for his master, and after questioning he confessed to the murder, implicating his

1. 7 Wigmore, Evidence $\$ 2072$ (3d ed. 1940); see also 2 Wharton, Crtaminal Evidence $\$ 640$ (11th ed. 1935).

2. See text at note 63 infra.

3. Perrys' Case, 14 How. St. Tr. 1312 (1660). 
brother and mother. The three were tried, convicted, and executed, solely on the basis of the disappearance of the allegedly murdered man, the finding of the hat, and the confession of the defendant. After a few years the master returned, stating that he had been waylaid, kidnapped and held as a slave in Turkey.

This and similar cases led the British courts to question the sufficiency of confessions to prove that a crime had been committed. Lord Matthew Hale, prompted by two cases which did not involve confessions but in which the defendants were convicted of murder solely on circumstantial evidence of death and in both of which the supposedly murdered man returned alive, maintained:

"I would never convict any person for stealing the goods cujusdam ignoti merely because he would not give an account of how he came by them, unless there were due proof made, that a felony was committed of these goods. . . . I would never convict any person of murder or manslaughter, unless the fact were proved to be done, or at least the body found dead. . . ."4

This statement is susceptible of two different interpretations: (1) the fact that a murder or manslaughter has been committed must be proved by finding the dead body with evidence of criminal causation, or as a minimal requirement the dead body must be found, ${ }^{5}$ or (2) if the body is not found, the fact that a death has occurred may be proved by circumstantial evidence. $^{6}$ The former interpretation would lead to the conclusion that defendant's confession is not sufficient for conviction without, at least, the dead body. Since it is stating the obvious to say that proof of death must precede conviction of murder or manslaughter, and since Hale used the words "at least" and was prompted by cases involving wrongful convictions grounded on circumstantial evidence, it seems probable that the former interpretation is correct; but interpretations of Hale in subsequent cases have been very ambiguous. ${ }^{7}$

In Queen v. Unkles, ${ }^{8}$ a prosecution for illegal communication of information at a polling place, the court, citing Hale, said by way of dictum that a defendant could not be convicted of murder on his confession unless the dead body is found. But the court also stated that this is "a rule of judicial practice" rather than part of the law of evidence. In Rex $v$.

4. 2 Hale, Pleas of the Crown 290 (1847).

5. This interpretation is given to Hale's statement in Queen v. Unkles, $8 \mathrm{Ir}$. R.C.L. 50, 58 (Q.B. 1873) ; United States v. Williams, 28 Fed. Cas. No. 16,707, at 642 (C.C.D. Me. 1858); cf. State v. Sogge, 36 N.D. 262, 275, 161 N.W. 1022, 1024 (1917).

6. This interpretation is given to Hale's statement in Rex v. Hindmarsh, 2 Leach C.C. 648, 650-51 (1792) (by implication); Edmonds v. State, 34 Ark. 720, 745 (1879); cf. Ruloff v. People, 18 N.Y. 179 (1858). See also letter from Director of Public Prosecutions, London, dated Sept. 18, 1954, on file in Biddle Law Library, University of Pennsylvania Law School.

7. Compare cases cited in note 5 supra, with cases cited in note 6 supra.

8. 8 Ir. R.C.L. 50 (1873). 
Kersey, ${ }^{9}$ the defendant's confession and medical testimony that she recently had given birth to a child were held insufficient evidence of murder of the child, since there was no evidence, other than the confession, that the child had been born alive. In 1913 in Rex $v$. Sykes, ${ }^{10}$ in which the court affirmed a conviction of murder on the basis of defendant's confession plus corroborating proof, the opinion was ambiguous ${ }^{11}$ as to whether the confession would have been sufficient by itself. Likewise, the 1934 case of Rex v. Davidson, ${ }^{12}$ in which a murder conviction was affirmed solely on the defendant's testimony, left unanswered the question of whether the defendant's confession out of court would have been sufficient.

Meanwhile, as a result of the "best evidence" principle ${ }^{13}$ the rule developed in England that the defendant's confession of a former marriage was not sufficient evidence upon which to found a bigamy conviction. ${ }^{14}$

Upon a review of the cases, if it can be said that the English courts adhere to any rule requiring evidence of the corpus delicti independent of the defendant's confession, the rule apparently applies to murder and bigamy only. ${ }^{15}$

\section{In the United States}

The unsettled state of the English law left the United States without any consistent doctrine to follow. However, once the rule had been established by a few courts in this country, other courts followed. The early cases developed from several lines of authority. Only one court laid down the rule in the belief that the English cases meant that a confession is insufficient if unsupported by other evidence. ${ }^{16}$ Some courts, motivated by both English and American cases in which there had been false convictions based on the defendant's confession, followed Hale's statement. ${ }^{17}$ Other courts, in establishing the rule, relied on statements by certain American authors that such was the law; ${ }^{18}$ and still other courts, without citing any

9. 21 Cox C.C. 690 (1908); see Rex v. McNicholl, [1917] 2 Ir. R. 557, in which a conviction of murder of an illegitimate infant was affirmed on defendant's confession plus other evidence; there was no statement that the other evidence was essential.

10. 8 Cr. App. R. 233 (1913).

11. Wigmore says that this case apparently requires evidence in addition to defendant's confession. 7 WIGMore, Evidence \& 2070, n.5 (3d ed. 1940). Two English authors, on the other hand, claim that this case holds the confession alone to be sufficient. Phipson, Evmence 266 (9th ed., Sweet \& Maxwe11, 1952); Roscoe, Criminal Evidence 38 (16th ed. 1952).

12. 25 Cr. App. R. 21 (1934).

13. See 7 Wigmore, Evidence $\$ 2084$ (3d ed. 1940).

14. Regina v. Savage, 13 Cox C.C. 178 (1876). But cf. Queen v. Newton, 2 Mo. \& R. 503 (1843). See 7 WIGMORE, EVIDENCE $\$ 2086$ (3d ed. 1940).

15. See Roscoe, Criminal Evidence 38 (16th ed. 1952).

16. People v. Hennessey, 15 Wend. 148 (N.Y. 1836).

17. United States v. Williams, 28 Fed. Cas. 636, No. 16,707 (C.C.D. Me. 1858); Smith v. Commonwealth, 21 Grat. 809 (Va. 1871); cf. Edmonds v. State, 34 Ark. 720,745 (1879).

18. E.g., Mose v. State, 36 Ala. 211, 232 (1860) (cites Wharton, AmIEricaN Criminal Law $\$ 683$, at $183(1846)$ ) ; United States v. Williams, 28 Fed. Cas. No. 16,707 , at 643 (C.C.D. Me. 1858) (quotes GREENLEAF [apparently 1 Evidence $\$ 216$ (2d ed. 1844)]). 
authority, discussed the various possible rationales and reached the conclusion that the corpus delicti must be proved aliunde the defendant's confession. ${ }^{19}$

While the English rule had been restricted to murder and bigamy, the American versions extended to almost all crimes. This expansion probably took place, depending on the source of the rule in the respective state, either because the rule was discussed in murder cases in general terms, because Hale's statement includes both robbery and murder, or because the rationale formulated by the courts was apparently as pertinent to other crimes as to murder. ${ }^{20}$

Today, evidence of the corpus delicti in addition to the defendant's confession is required by statute in nine states ${ }^{21}$ and by judicial decision ${ }^{22}$ in thirty-two other states, seven federal circuits and the Court of Appeals for the District of Columbia. Three states and two federal circuits require some extrinsic evidence of a corroborative nature lending credence to the confession but not necessarily proving the corpus delicti. ${ }^{23}$ Massachusetts ${ }^{24}$

19. Stringfellow v. State, 26 Miss. 157 (Ct. Err. \& App. 1853) ; State v. Long, 1 Haywood (2 N.C.) 455 (Super. Ct. 1797).

20. See State v. Geltzeiler, 101 N.J.I. 415, 128 Atl. 240 (1925).

21. Ark. Stat. Ann. \$43-2115 (1947); Ga. Code Ann. \$38-420 (Rev. ed. 1954); Iowa Code ANN. \$782.7 (1950); Ky. Codes, CrIM. PRAC. \$240 (1948); Minn. Stat. Ann. §634.03 (1947); Mont. Rev. Codes Ann. \$ 94-2510 (1949); N.Y. Code Crim. Proc. \$395; N.D. Rev. Code \$12-2729 (1943) ; Ore. Comp. Laws ANN. \$26-937 (1940).

22. United States v. Markman, 193 F.2d 574 (2d Cir. 1952) ; United States v. Di Orio, 150 F.2d 938 (3d Cir.), cert. denied, 326 U.S. 771 (1945); Bell v. United States, 185 F.2d 302 (4th Cir. 1950), cert. denied, 340 U.S. 930 (1951); Vogt v. United States, 156 F.2d 308 (5th Cir. 1946) ; United States v. Angel, 201 F.2d 531 (7th Cir. 1953); Gulotta v. United States, 113 F.2d 683 (8th Cir. 1940); Manning v. United States, 215 F.2d 945 (10th Cir. 1954); Forte v. United States, 94 F.2d 236 (D.C. Cir.), on certified questions, 302 U.S. 220 (1937) ; Rutland v. State, 31 Ala. App. 43, 11 So.2d 768 (1943) ; State v. Romo, 66 Ariz. 174, 185 P.2d 757 (1947) ; People v. Frey, 165 Cal. 140, 131 Pac. 127 (1913) ; State v. Guastamachio, 137 Conn. 179, 75 A.2d 429 (1950) ; State v. Kohm, 103 A.2d 781 (Del. Super. Ct. 1954); McElveen v. State, 72 So.2d 785 (Fla. 1954); State v. Downing, 23 Idaho 540, 130 Pac. 461 (1913) ; People v. Gavurnik, 2 I11.2d 190, 117 N.E.2d 782 (1954); Dennis v. State, 230 Ind. 210, 102 N.E.2d 650 (1952); State v. Morgan, 157 La. 962, 103 So. 278 (1925); State v. Jones, 108 A.2d 261 (Me. 1954); Davis v. State, 202 Md. 463, 97 A.2d 303 (1953) ; People v. Coapman, 326 Mich. 321, 40 N.W.2d 167 (1949); Buford v. State, 69 So.2d 826 (Miss. 1954); State v. Thompson, 333 Mo. 1069, 64 S.W.2d 277 (1933); Gallegos v. State, 152 Neb. 831, 43 N.W.2d 1 (1950) ; State v. Fouquette, 67 Nev. 505, 221 P.2d 404 (1950); State v. Lindemuth, 56 N.M. 257, 243 P.2d 325 (1952); State v. Cope, 240 N.C. 244, 81 S.E.2d 773 (1954); State v. Maranda, 94 Ohio St. 364, 114, N.E. 1038 (1916) ; Brown v. State, 274 P.2d 779 (Okla. Crim. App. 1954) ; Commonwealth v. Lettrich, $346 \mathrm{~Pa} .497$, 31 A.2d 155 (1943); State v. Boswell, 73 R.I. 358, 56 A.2d 196 (1947); State v. Thomas, 222 S.C. 484, 73 S.E.2d 722 (1952); Taylor v. State, 191 Tenn. 670, 235 S.W.2d 818, cert. denied, 340 U.S. 918 (1951); Cohron v. State, 156 Tex. Crim. Rep. 331, 242 S.W.2d 776 (1951); State v. Ferry, 275 P.2d. 173 (Utah 1954); Cambell v. Commonwealth, 194 Va. 825, 75 S.E.2d 468 (1953) ; State v. Longe, 96 Vt. 7, 116 Atl. 81 (1922); State v. Meyer, 37 Wash.2d 759, 226 P.2d 204 (1951); State v. Blackwell, 102 W. Va. 421, 135 S.E. 393 (1926); Curran v. State, 12 Wyo. 553, 76 Pac. 577 (1904).

23. See note 137 infra.

24. Commonwealth v. Kimball, 321 Mass. 290,73 N.E.2d 468 (1947) ; Commonwealth v. Zelenski, 287 Mass. 125, 191 N.E. 355 (1934). 
and Wisconsin ${ }^{25}$ disclaim adherence to any rule requiring such evidence, and the New Hampshire ${ }^{26}$ and South Dakota courts have been completely silent on the subject.

\section{Rationale}

The courts seldom have articulated a rationale for the corpus delicti rule. When cases come up in the "gray area" where it is not certain whether the rule should apply, the courts usually base their results on the great weight of judicial authority in support of the rule, rather than on an independent rationale. Moreover, when discussed, the rationale rarely is lucid and at best seems to be composed of one or more of several factors.

The most pertinent of these factors is the general distrust of confessions which permeates the thinking of many courts, ${ }^{27}$ coupled with the

25. Potman v. State, 259 Wis. 234, 47 N.W.2d 884 (1951).

26. But cf. Washburn v. Washburn, 5 N.H. 195 (1830) (confession of adultery in divorce action must be corroborated). See State v. Sander, Hillsborough County, N.H. 1950, N.Y. Times, March 10, 1950, p. 1, col. 6, discussed in 48 MICH. L. REv. 1197 (1950), in which defendant, a doctor, was prosecuted for the murder of a cancer patient by injecting air into her blood stream. Defendant had noted the injection on a chart and had confessed to his nurse and later to the authorities. A pathologist testified that death was caused by the disease rather than by the injection. Defendant did not object that the corpus delicti had not been proved aliunde his confession but instead permitted the case to go to the jury, which returned a verdict of not guilty.

Conrad Danais, County Solicitor of Hillsborough County, N.H., stated in a letter dated Dec. 27, 1954: "The policy of my office as County Solictor in seeking indictments in cases where the only evidence that a crime was committed is the confession of the defendant is that such cases should be nol prossed. I am of the opinion that there must be corroboration of the crime other than the confession of the defendant by itself." Letter on file in Biddle Law Library, University of Pennsylvania Law School.

27. Blackstone considered confessions "the weakest and most suspicious of all testimony, ever liable to be obtained by artifice, false hopes, promises of favor or menaces." 4 BL. Comar. *357. See Foster, J., to the same effect in the Case of Francis Francia (1716) discussed in 1 EAst, Pleas of rHe Crown 133 (1803). This view was not universal, however. Russel felt that a confession was "the highest and most satisfactory proof, because it is fairly presumed that no man would make such a confession against himself, if the facts confessed were not true." 2 RUSSEL, Crimes 824 (8th Am. ed. 1857); see also Roscoe, Criminal Evidence 28 (16th ed. 1952).

American courts on the whole seem to have followed Blackstone's reasoning:

"The grounds on which the rule requiring independent proof of the corpus delicti rests are the hasty and unguarded character which confessions often have, the temptation which for one reason or another a person may have to say that which he thinks it most for his interest to say, whether true or false. . . "State v. Saltzman, 241 Iowa 1373, 1379, 44 N.W.2d 24, 27 (1950) (quoting with approval 20 AM. Jur. 1086 (1939)). See also State v. Dena, 28 N.M. 479, 483, 214 Pac. 583, 585 (1923); Commonwealth v. Turza, $340 \mathrm{~Pa} .128,134,16$ A.2d 401, 404 (1940); Commonwealth v. Chuing, $150 \mathrm{~Pa}$. Super. 445, 452, 28 A.2d 710,713 (1942); Mackey v. State, 30 Okla. Cr. 31, 33, 234 Pac. 782, 783 (1925); Boyle v. State, 27 Okla. Cr. 196, 197, 226 Pac. 389, 390 (1924). "It is also true that evidence as to confessions of parties is intrinsically weak and is inconclusive to establish a fact without the aid of other testimony. . . " Collins v. Commonwealth, 123 Va. 815, 821, 96 S.E. 826, 828 (1918).

Massachusetts has followed Russel's theory and abolished the rule, claiming there are sufficient safeguards against involuntary confessions and innocent people do not voluntarily confess to crimes which they have not committed. Commonwealth v. Killon, 194 Mass. 153, 155, 80 N.E. 222, 223 (1907). The Missouri Supreme Court 
extreme difficulty that the defendant would have disproving his confession once it had been introduced in evidence. ${ }^{28}$ This distrust stems from a number of considerations. There is always the danger that a confession made out of court will be misreported or misconstrued. ${ }^{29}$ Furthermore, even though there are rules of evidence protecting the defendant from confessions elicited through force or coercion, he is protected only so far as he is able to prove that his confession was not "voluntary." Difficulty of proof might easily make this protection inadequate, ${ }^{30}$ since usually the only witnesses to third degree methods are the police and the defendant himself; and it is possible for police methods to be so subtle that even if the defendant can prove what went on in the room in the rear of the police station, he has not shown sufficient duress to convince a court that his confession was "involuntary." 31 Even when the police have, in fact, done nothing to make his confession "involuntary," the defendant might think that it is in his own best interest to make a false confession, as where the defendant wants to be convicted and put in prison because he fears the lynch mob, ${ }^{32}$ or where, faced with overwhelming circumstantial evidence, the defendant confesses in the hope of obtaining a lighter sentence. ${ }^{33}$

A further basis for distrust of confessions is the possibility that the defendant may be mistaken in what he confesses, either as to the facts or as to the law. ${ }^{34}$ Where the defendant confesses that he murdered the "deceased" by hitting him on the head, it is possible that he was not in fact killed; ${ }^{35}$ where the defendant confesses that he murdered the "deceased"

felt that: "No definite rules can be prescribed for ascertaining the credit to be given to confessions any more than to the evidence of witnesses. The weight to be attached to a confession . . . must depend upon the circumstances." State v. Lamb, $28 \mathrm{Mo}$. 218,230 (1859).

28. State v. Saltzman, 241 Iowa 1373, 1379, 44 N.W.2d 24, 27 (1950); State v. Dena, 28 N.M. 479, 483, 214 Pac. 583, 585 (1923) ; Commonwealth v. Turza, 340 Pa. 128, 134, 16 A.2d 401, 404 (1940); Commonwealth v. Chuing, 150 Pa. Super. 445, 452, 28 A.2d 710, 713 (1942); Mackey v. State, 30 Okla. Cr. 31, 33, 234 Pac. 782, 783 (1925); Boyle v. State, 27 Okla. Cr. 196, 197, 226 Pac. 389, 390 (1924).

"[Confessions are] incapable in their nature of being disproved by other negative evidence." $4 \mathrm{Bz}$. Consa. *357.

29. See cases cited in note 28 supra; Best, Evidence 522 (3d Am. ed. 1908).

"Hasty confessions made to persons having no authority to examine are the weakest and most suspicious of all evidence; words are often misreported, and extremely liable to misconstruction." People v. Hennessey, 15 Wend. 148, 153 (N.X. 1836). But see Commonwealth v. Killon, 194 Mass. 153, 155, 80 N.E. 222, 223 (1907), in which the court stated that there is no greater liability to misconstrue or misreport in the case of confessions than in any situation in which someone reports what another has said.

30. See Smith v. United States, 75 Sup. Ct. 194, 197 (1954).

31. On third degree methods generally, see Note, 43 HARv. L. REv. 617 (1930).

32. See, e.g., Case of John A. Johnson (Wisconsin, 1911), in Borchard, ConVICTING THE INNOCENT 112 (1932).

33. See, e.g., Case of James Willis (California, 1927), in BorCrard, op. cit. supra note 32 , at 367 . See also MUENSTERBERg, ON THE WITNEsS STAND 144-45 (1923).

34. See generally Best, Evidence $\$ \$ 560-62$ (3d Am. ed. 1908).

35. This possibility is discussed in Wharron, Criminal Evidence 512 (8th ed. 1880). 
by shooting him, it is possible that the victim already was dead; ${ }^{36}$ where the defendant confesses that he murdered the "deceased" by throwing him overboard near shore or near another ship, he may have survived; ${ }^{\mathbf{3 7}}$ or where the defendant confesses that she smothered her illegitimate infant as it was born, the baby may have been stillborn. ${ }^{38}$ The possibility of a mistake of law exists in the case where a German immigrant who is unable to speak English and who is ignorant of the difference between murder and non-criminal homicide confesses to murder through an interpreter. ${ }^{39}$ However, in many types of factual situations there is no danger of mistake. Although in a murder case the defendant might be mistaken as to whether he killed the deceased, it is difficult to imagine a burglary case in which the defendant could be mistaken as to whether he broke and entered the building with the intention to commit a felony.

Finally, some courts are aware that voluntary confessions are sometimes false for purely psychological reasons. ${ }^{40}$ The psychologists recognize that there are certain mental disorders which might lead a person to think that he actually has committed a crime which has in fact never been committed. ${ }^{41}$ The most extreme of these disorders, and the easiest to diagnose, is a form of psychosis known as melancholia. The smallest sins of which a psychotic of this type has actually been guilty become enormously magnified in his mind. The last fire in town becomes an arson committed by him; he becomes guilty of having murdered his friend who died years ago. ${ }^{42}$ One patient who had failed to return a book to the college library had vivid fantasies of being Jack the Ripper. ${ }^{43}$ A less extreme mental disorder, practically impossible to diagnose, is a temporary hysterical and autohypnotic abnormal state which may occur in an otherwise normal mind. ${ }^{44}$ Classic examples of this form of derangement leading to false confessions are the cases of the Salem witches, who confessed to the crimes of which they were accused really believing themselves to be guilty. A dissociation of their minds set in; emotional shock caused the normal personality to go to pieces, and a split-off second personality then began to form with its own connected life story built up from the absurd superstitions which had been suggested to them through hypnotizing examinations. This type

36. This possibility is discussed in id. at 509 .

37. This possibility is discussed in United States v. Williams, 28 Fed. Cas. No. 16,707 , at 643 (C.C.D. Me. 1858).

38. This may have been the rationale of the court in State v. Johnson, 95 Utah 572, 83 P.2d 1010 (1938).

39. See Gardner v. People, 106 Ill. 76 (1883) ; see also Best, Evidence $\$ 562$ (3d Am. ed. 1908).

40. See Smith v. United States, 75 Sup. Ct. 194, 197 (1954); State v. Long, 1 Hay. (2 N.C.) 455,456 (Super. Ct. 1797).

41. Much of the following discussion is based on MUENSTERberg, ON THE WITNESS STAND 148-49 (1923).

42. Ibid. See also Burrt, Legal Psychorogy 173-74 (1931).

43. Lorand, Crime in Fantasy and Dreams and the Neurotic Criminal, 17 Psychoanalytic Rev. 183, 186 (1930).

44. Muensterberg, ON the Witness Stand 149 (1923). 
of confession is given with real conviction under the pressure of emotional excitement or under the spell of overpowering influences. Even mere fatigue, the loosening of the mental firmness and the intrusion of the suggestion of guilt from long periods of questioning might lead to such false confessions. The reports of the Salem witch trials agree that once the accused decided to confess they fabricated their stories with ingenious facts to make them tally with the statements of their accusers, adding points that gave the stories an air of truthfulness. ${ }^{45}$

In an Illinois case ${ }^{46}$ the defendant confessed to burglary one day after he had been adjudicated insane in a prosecution for a previous crime. The court held that this confession was inadmissible since not made voluntarily. "An insane person can commit no rational, voluntary act. He can do nothing intentionally. Neither can he know of his constitutional right. His confession is a nullity." 47 On the other hand, California has held that the confession is admissible along with evidence that the defendant was insane at the time he confessed, and the jury is to be instructed that it can disregard the confession if it finds the defendant mentally incompetent. 48 In any case it seems that in the absence of total insanity the confession is admissible, and evidence of the defendant's mental inability goes merely to the weight to be given the confession..$^{49}$

In view of the observations of the psychologists, even the Illinois rule on admissibility of confessions by insane people would seem insufficient to protect the defendant for several reasons. First, the defendant must be examined within a reasonable period of the making of the confession or testimony as to his sanity at that time will be of little validity. Second, assuming that he was examined and thought to be insane by the doctors, if there is contradictory evidence the jury is allowed to find the defendant sane. In the California case mentioned above, the jury believed the defendant to be sane in the face of testimony by four psychiatrists and some lay witnesses that the defendant was insane. Rarely will the defendant have been adjudicated insane before he confesses. Finally, as illustrated by the confessions in the Salem witch trials, a mental disorder need not rise to the height of total insanity to result in a person's believing himself guilty of a crime which was never committed. This belief might be the result of a temporary derangement of an otherwise perfectly normal mind. Even if the defendant could prove that this temporary disorder had existed at the time he confessed, under the present rules of evidence his confession would be admissible and he would be confronted with the almost insurmountable task of convincing the jury that, because of a psychological state

45. Id. at 146, 149.

46. People v. Shroyer, 336 I1l. 324, 168 N.E. 336 (1929). See also State v. Campbell, 301 Mo. 618, 257 S.W. 131 (1923).

47. People v. Shroyer, 336 Ill. 324, 326, 168 N.E. 336 (1929).

48. People v. Rucker, 11 Cal. App.2d 609, 54 P.2d 508 (1936).

49. McAffee v. United States, 111 F.2d 199 (D.C. Cir.), cert. denied, 310 U.S.

643 (1940); Vinzant v. State, 28 Ala. App. 220, 180 So. 736 (1938). 
which it is difficult for the average layman to understand, his confession is false. ${ }^{\text {to }}$

A second major factor underlying the corpus delicti rule is the shock to the consciences of the courts which results from cases in which the "deceased" returns alive after his supposed murderer has been tried and convicted, and in some instances executed. ${ }^{51}$ The case of the Boorn brothers in Vermont in $1812,,^{52}$ for instance, had a marked effect on the courts of this country.53 Russel Colvin, the defendants' brother-in-law, had the peculiar habit of disappearing, sometimes for as long as eight or nine months, and therefore his disappearance in the spring of 1812 was hardly noticed at first. But a series of events led to the supposition that he had been murdered. An old dilapidated hat identified as having been worn by Colvin when last seen was found close to the place where he had been seen in a heated quarrel with the Boorn brothers. A repeated dream of the defendants' uncle in which Colvin related how he had been murdered by the defendants did much to stir the countryside. A button and knife said to be Colvin's were found in the place in which, according to the uncle's dream, Colvin had said he had been buried. The defendants' barn burned and it was rumored that the burning was to conceal evidence of the murder. Some bones were unearthed by a dog and were summarily pronounced to be human, but were later found to be an animal's. By this time seven years had passed since the disappearance, and there was still no definite evidence of murder. But shortly thereafter Jesse Boorn made a statement accusing his brother of the murder; still no body was found. Both brothers were arrested and before trial each made a confession of the murder. They were tried, convicted and sentenced to be hanged. Within two months of the day set for execution a newspaper advertisement led to the discovery of Colvin, who had been living in New Jersey under

50. See note 28 supra. "To recognize where the temperament ends and the irresponsible disturbance begins is made extremely difficult by the great breadth of the border land region. Public opinion, and court and jury as its organs, are always inclined to claim that whole borderland field still for the normal life and to acknowledge the mental disturbance only when the disease region is entered." Muensterberg, ON the Witness Stand 153 (1923).

51. See Smith v. United States, 75 Sup. Ct. 194, 197 (1954). "The controlling reason for the rule that the mere confession of a criminal is insufficient to sustain a conviction arose from the fact that in some instances persons have been convicted upon such confessions, and thereafter the supposed victim turned up alive. While these occurrences were infrequent, they were sufficient in number to cause the courts in the first instance, and later the legislative power, to require that such confessions should be corroborated by extraneous evidence that the death had been occasioned by some criminal agency so as to preclude the presumption that it happened through accident or suicide." State v. Howard, 102 Ore. 431, 439, 203 Pac. 311, 314 (1921).

52. The Trial of Stephen and Jesse Boorn (Vermont, 1812), 6 Am. St. Trials 73 (1916); There is an excellent discussion of this case in BORCEARD, Convicting THE INNOCENT 15 (1932).

53. The Minnesota Supreme Court in discussing the need for a rule requiring extrinsic proof of the corpus delicti, cited the unfortunate conviction in the Boorn case. State v. Laliyer, 4 Minn. 368, $376(1860)$. The case is also cited in 1 Greenleaf, Evidence 256-57 n.2 (2d ed. 1844), and in Wharton, Criminal EvxDENCE 512 n.1 (8th ed. 1880), which texts led to the establishment of the rule by at least two courts. See note 18 supra. Wharton also cites a similar case involving the Trailor Brothers, Illinois, 1841. Ibid. 
an assumed name. Requiring proof of the corpus delicti independent of the defendant's confession seems to be the logical method of preventing convictions like that in the Boorn case.

Third, some courts explain the need for the rule in terms very similar to the "best evidence rule." For example, the best way to prove that there has been a death and to ascertain its cause is by finding and inspecting the body, but, where this is shown to be impossible because the body has been destroyed or is inaccessible, circumstantial evidence may suffice. ${ }^{54}$ Similarly, the best way to prove a robbery is by having the victim testify. ${ }^{55}$ Courts which follow this line of reasoning as a general proposition classify confessions as inferior to both direct and circumstantial evidence of the crime. In some situations, however, the best evidence of at least part of the corpus delicti would be the defendant's confession, as for example, the scienter in transporting a car across the state line knowing it to be stolen.

The fourth factor is the apparent desire of some courts to force the prosecution to produce as much evidence of the crime as it is possible to gather, instead of permitting reliance on the defendant's confession alone. ${ }^{56}$ Two early New York cases illustrate this reasoning. In the first of these the court, in reversing a conviction of embezzlement based solely on the defendant's confession, said:

"The truth is, no court will ever rely upon the confessions alone, when it is apparent that there is evidence aliunde to prove that an offense has been committed. In the case now before us, it was manifest that there were witnesses not before the court who could have given material testimony to prove the facts essential to the body of the offense." 57

In the second case the same court affirmed a conviction of forgery, distinguishing the earlier opinion on the ground that in the former case the defrauded victims were available to testify but had not been called, while in the case at bar the alleged maker of the promissory note in question had not been called because he had died before trial. "The highest and best evidence in the power of the prosecutor was produced. . . ." 58

The last and most nebulous of all the factors is the adverse emotional reaction of the courts to a conviction in which the only evidence adduced is the confession of the accused, especially where the defendant has repudiated his confession. Often cited in support of the rule is Greenleaf's observation in his discussion of independent proof of the corpus delicti: “. . . [T] his opinion certainly best accords with the humanity of the

54. Edmonds v. State, 34 Ark. 720, $744-46$ (1879) (no confession involved).

55. Cf. People v. Jones, 31 Cal. 565, 572 (1867).

56. See Smith v. United States, 75 Sup. Ct. 194, 197 (1954).

57. People v. Hennessey, 15 Wend. 147, 155 (N.Y. 1836); see also In re Flodstrom, 277 P.2d 101 (Cal. App. 1954).

58. People v. Badgley, 16 Wend. 53, 59 (N.Y. 1836) ; cf. People v. Wulff, 313 III. 286,145 N.E. 108 (1924). 
criminal code. . . ."59 This basis for adherence to the corpus delicti rule is somewhat similar to that which supports the right against selfincrimination. In both instances the courts indicate a reluctance to convict a person solely on the basis of his own statements, even though he may in fact be guilty.

Some of these factors relied on in support of the corpus delicti rule, if carried to their logical conclusions, would require independent evidence of the whole charge, including the defendant's agency ${ }^{60}$ But under the corpus delicti rule as it now exists the confession by itself is sufficient to prove that the defendant was the perpetrator of the crime. ${ }^{61}$ If there is a chance that the defendant's confession was not voluntary, the confession should not be sufficient by itself to prove that the defendant committed the crime any more than it should be sufficient to prove that a crime was committed. As a matter of fact, it would seem that the greatest danger that the police will use third degree methods or that the defendant will succumb to the suggestive influence of long hours of questioning by the police exists where there is some independent evidence that a crime was committed, which has led the police to undertake an investigation. Likewise, the danger of a pathological confession would be as great where the question is who committed a crime as where the question is whether a crime was committed. Similarly, there is no clear reason why the adverse emotional reaction of the courts to conviction based solely on the defendant's confession should be confined to his statements which tend to prove the corpus delicti. And finally, it seems desirable that the prosecution produce as much evidence as possible with respect to all elements of the crime, not only with respect to the corpus delicti.

On the other hand, this reasoning for the most part is not applicable to the other factors. It seems that courts would be shocked to a greater degree by a case in which positive proof of a false conviction turns up in the form of a person supposed to have been murdered, than by a case in which a person other than the convicted defendant was later shown to be the criminal. And, although the best way to prove that a crime was committed is by direct or circumstantial evidence rather than by the confession of the defendant, the confession would rate higher on the scale of proof as evidence that the defendant committed the crime. Similarly, the danger that the defendant might be mistaken about the occurrence as to which he confessed lies usually in the possibility that he was mistaken as to whether a crime was committed. If that is established, there is almost no danger that the defendant was mistaken as to whether he was the person who

59. 1 Greenleaf, Evidence 260 (2d ed. 1844), cited in State v. Laliyer, 4 Minn. 61. See note 63 infra.

368, 376 (1860) ; State v. Dena, 28 N.M. 479, 483, 214 Pac. 583, 585 (1923) ; Mackey v. State, 30 Okla. Cr. 31, 33, 234 Pac. 782, 783 (1925); Boyle v. State, 27 Okla. Cr. 196, 197, 226 Pac. 389, 390 (1924); Commonwealth v. Turza, $340 \mathrm{~Pa}$ 128, 134, 16 A.2d 401, 404 (1940); Commonwealth v. Chuing, $150 \mathrm{~Pa}$. Super. 445, 452, 28 A.2d 710, 713 (1942).

60. See text at note 70 infra. 
committed the criminal act. An exception to this proposition would be the rather unlikely case where the defendant and someone else shoot at the deceased simultaneously, and the defendant's bullet strikes the deceased after he has been killed by the other.

To the extent that there is a conflict between the logic behind the various theories and the limitation of the requirement of independent evidence to proof of the corpus delicti, the present rule seems almost to be a compromise between two extremes: requiring proof of all elements of the crime independent of the confession, or requiring no independent evidence at all. The former alternative would undoubtedly make it almost impossible to obtain convictions in many cases where the defendant is guilty; the latter would afford no protection whatsoever to the individuals who would be wrongly convicted.

\section{Definition of CoRpus Delicti ${ }^{82}$}

Today, every jurisdiction in the United States which has a rule requiring proof of the corpus delicti aliunde the defendant's confession defines corpus delicti as including the first two elements of the crime, i.e., the injury and the criminality. ${ }^{63}$ Although the North Dakota Supreme

62. "The use of Latin words, e.g. "corpus delicti," "res gestae" and the like, in the law of evidence, do [sic] not tend to throw much light upon the subject. Not infrequently one feels justified in suspecting that when a judge says evidence is admissible because it is part of the "res gestae", or says a confession is not admissible because the "corpus delicti" has not been proved, the judge has a hunch it should be admissible or inadmissible, as the case may be, and resorts to a foreign language he doesn't understand for a reason." Ritter, J., in Manning v. United States, 215 F.2d 945, 946 (10th Cir. 1954).

Often the layman thinks of the corpus delicti as the body of the dead person in a murder case. Perhaps the cause of such thinking can be found in the following statements: "The finding of a dead body establishes only the corpus. The finding of such body under circumstances that indicate a crime would indicate the delicti or felonious killing." 1 Wharton, CrIMINal Evidence \$325 (10th ed. 1912). "While it [the corpus delicti] is generally defined as the body of a crime, it is more clearly expressed by calling it the body or thing which is the victim of a wrong. The body of a man produced under circumstances that show a felony is corpus delicti in homicide." Id. \$325 n.4.

63. Alabanfa: Peoples v. State, 256 Ala. 612, 56 So.2d 665 (1952); Phillips v. State, 248 Ala 510, 28 So.2d 542 (1946); Daniels v. State, 12 Ala Ápp. 119, 68 So. 499 (1915). ArIzona: State V. Benham, 58 Ariz. 129, 118 P.2d 91 (1941). ArRansas: ARK. Stat. Ann. \$43-2115 (1947); Ezell v. State, 217 Ark. 94, 229 S.W.2d 32 (1950); Edmonds v. State, 34 Ark 720 (1879). CalmornIA: People v. Holman, 72 Cal. App.2d 75, 164 P.2d 297 (1945) ; People v. Sameniego, 118 Cal. App. 165, 4 P.2d 809 (1931); People v. Tarbox, 115 Cal. 57, 46 Pac. 896 (1896). Connecticut: State v. Guastamachio, 137 Conn. 179, 75 A.2d 429 (1950). DELAWARE: State v. Galvano, 34 Del. (4 Harring) 409, 154 Atl. 461 (Ct. Oyer \& Ter. 1930). Frorida: McElveen v. State, 72 So.2d 785 (Fla. 1954); Holland v. State, 39 Fla. 178, 22 So. 298 (1897). GrorgIA: McVeigh v. State, 205 Ga. 326, 53 S.E.2d 462 (1949); Clay v. State, $176 \mathrm{Ga} .403,168$ S.E. 289 (1933). IDAmo: State v. Keller, 8 Idaho 699, 70 Pac. 1051 (1902). IrLrNors: People v. Manske, 399 I11. 176, 77 N.E.2d 164 (1948); People v. Harrison, 261 IIl. 517, 104 N.E. 259 (1914). InDIANA: Dennis v. State, 230 Ind. 210, 102 N.E.2d 650 (1952); Parker v. State, 228 Ind. 1, 88 N.E.2d 556 (1949), rehearing denied, 228 Ind. 11, 89 N.E.2d 442 (1950). IowA: Iowa Code ANn. \$ 782.7 (1946). Kentucky: KY. Cones, Crim. Prac. \& 240 (1948); Warmke v. Commonwealth, 297 Ky. 649, 180 S.W.2d 872 (1944). LouIsIANA: State y. Morgan, 157 La 962 , 103 So. 278 (1925). MarNe: State v. Levesque, 146 Me. 351, 81 A.2d 665 (1951). Maryland: Weller v. State, 150 Md 278, 132 At1. 
Court defines corpus delicti as including both the injury and the criminality, ${ }^{64}$ it requires independent proof of the injury only, on the basis of a statute which says:

"In a prosecution for murder, manslaughter, or aiding suicide . . . a confession or admission of the accused . . . shall not be admissible to establish the death of the person alleged to have been killed." 65

624 (1926). Michigan : People v. Coapman, 326 Mich. 321, 40 N.W.2d 167 (1949); People v. Mondich, 234 Mich. 590, 208 N.W. 675 (1926). Minnesota: Minn. Stat. ANN. \$634.03 (West 1945); State v. Grear, 29 Minn. 221, 13 N.W. 140 (1882); State v. Laliyer, 4 Minn. 368 (1860). MississIPPI: Rogers v. State, 76 So.2d 831 (Miss. 1955) ; Buford v. State, 69 So.2d 826 (Miss. 1954) ; Garner v. State, 132 Miss. 815, 96 So. 743 (1923) ; Pitts v. State, 43 Miss. 472 (1870). Missourr: State v. Hubbard, 351 Mo. 143, 171 S.W.2d 701 (1943); State v. Hawkins, 165 S.W.2d 644 (Mo. 1942); State v. Garrison, 342 Mo. 453, 116 S.W.2d 23 (1938). Montana: State v. Ratkovich, 111 Mont. 9, 105 P.2d 679 (1940). NebRAskA: Gallegos v. State, 152 Neb. 831, 43 N.W.2d 1 (1950). NevadA: State v. Fouquette, 67 Nev. 505, 221 P.2d 404 (1950). NEW Mexico: State v. Jones, 52 N.M. 118, 192 P.2d 559 (1948). New YoRk: N.Y. Code CrTM. Proc. \$395; People v. Deacons, 109 N.Y. 374, 16 N.E. 676 (1888). North Carolina: State v. Cope, 81 S.E.2d 773 (N.C. 1954). Oнro: State v. Maranda, 94 Ohio St. 364, 114 N.E. 1038 (1916); State v. Arnold, 63 N.E.2d 31 (Ohio Ct. App. 1945). OrLAhoma: Brown v. State, 274 P.2d 779 (Okla. Crim. App. 1954); Ridinger v. State, 267 P.2d 175 (Okla. Crim. App. 1953); Leeks v. State, 95 Okla. Cr. 326, 245 P.2d 764 (1952); Osborn v. State, 86 Okla. Cr. 259, 194 P.2d 176 (1948); Choate v. State, 12 Okla. Cr. 560, 160 Pac. 34 (1916). OREGON: ORE. COMP. LAWS ANN. \$26-937 (1940); State v. Henderson, 182 Ore. 147, 184 P.2d 392 (1947); State v. Elwell, 105 Ore. 282, 209 Pac. 616 (1922); State v. Weston, 102 Ore. 102, 201 Pac. 1083 (1921); State v. Rogoway, 45 Ore. 601,78 Pac. 987 (1904), reversed on other grounds at rehearing, 45 Ore. 611, 81 Pac. 234 (1905). Pennsylvania: Commonwealth v. Lettrich, 346 Pa. 497, 31 A.2d 155 (1943); Commonwealth v. Danarowicz, 294 Pa. 190, 144 Atl. 127 (1928); Commonwealth v. Puglise, $276 \mathrm{~Pa} .235,120$ Atl. 401 (1923); Gray v. Commonwealth, $101 \mathrm{~Pa} .380$ (1882); Commonwealth v. Winter, $174 \mathrm{~Pa}$. Super. 35, 98 A.2d 221 (1953) ; Commonwealth v. Chuing, 150 Pa. Super. 445, 28 A.2d 710 (1942). Rhode Island: State v. Boswell, 73 R.I. 358, 56 A.2d 196 (1947); State v. Jacobs, 21 R.I. 259, 43 Atl. 31 (1899). South Carolina: State v. Thomas, 222 S.C. 484, 73 S.E.2d 722 (1952). TEN 670, 235 S.W.2d 818 (1950), cert. denied, 340 U.S. 918 (1951); Ashby v. State, 124 Tenn. 684, 139 S.W. 872 (1911). Texas: McDaniel v. State, 144 Tex. Crim. Rep. 168, 161 S.W.2d 1064 (1942); Lott v. State, 141 Tex. Crim. Rep. 366, 148 S.W.2d 1102 (1941); Estes v. State, 274 S.W.2d 402 (Tex. Ct. Crim. App. 1955). UTAF: State v. Johnson, 95 Utah 572, 83 P.2d 1010 (1938). VerMonT: State v. Longe, 96 Vt. 7, 116 At1. 81 (1922). WAsHingron: State v. Lutes, 38 Wash.2d 475, 230 P.2d 786 (1951) ; State v. Meyer, 37 Wash.2d 759, 226 P.2d 204 (1951); State v. Van Brunt, 22 Wash.2d 103, 154 P.2d 606 (1944). VIrganIA : Wheeler v. Commonwealth, 192 Va. 665,66 S.E.2d 605 (1951); Collins v. Commonwealth, 123 Va. 815, 96 S.E. 826 (1918). WEST VIRGINIA: cf. State v. Harrison, 98 W. Va. 227, 127 S.E. 55 (1925); State v. Merrill, 72 W. Va. 500, 78 S.E. 699 (1913). WYoming: Dalzell v. State, 7 Wyo. 450, 53 Pac. 297 (1898). FEDERAL: $2 d$ Cir.: United States v. Markman, 193 F.2d 574 (2d Cir. 1951), 3d Cir.: United States v. Di Orio, 150 F.2d 938 (3d Cir.), cert. denied, 326 U.S. 771 (1945). 4th Cir.: United States v. Washington, 69 F. Supp. 143 (D. Md. 1946); cf. Tabor v. United States, 152 F.2d 254, 257 (4th Cir. 1945) (cites Forte case infra with approval). 5th Cir.: Vogt v. United States, 156 F.2d 308 (5th Cir. 1946). Tth Cir.: cf. United States v. Angel, 201 F.2d 531, 533 (7th Cir. 1953) (cites Vogt case supra with approval). 8th Cir.: Gulotta v. United States, 113 F.2d 683, 685 (8th Cir. 1940) (cites Forte case infra with approval). 10th Cir.: Manning v. United States 215 F.2d 945 (10th Cir. 1954). D.C. Cir.: Forte v. United States, 94 F.2d 236 (D.C. Cir.), on certified questions, 302 U.S 220 (1937).

64. State v. Sogge, 36 N.D. 262, 161 N.W. 1022, 1023 (1917) (no confession involved).

65. N.D. REv. CODE § 12-2729 (1943). 
In reviewing a conviction for murder in the second degree in which a dead body had been found with strong evidence of suicide, the North Dakota Supreme Court rejected the defendant's argument that his confession of murder was not sufficient by itself to prove that the death was criminally caused; the court ruled: "It is only the fact of death that the statute says may not be established by the confession or admission of the accused." 66 There is some early authority in other jurisdictions for defining corpus delicti in terms of the injury only, ${ }^{67}$ but these cases are not followed today. ${ }^{68}$ In contrast, some courts had previously defined corpus delicti as composed of all three elements of the crime, including the defendant's participation as well as the basic injury and the criminal cause. ${ }^{69}$ Professor Wigmore refers to such a definition as "absurd" since it requires proof of the entire case without utilizing the defendant's confession, ${ }^{70}$ and today no court adheres to such a definition. ${ }^{71}$ In many crimes, however, it is very difficult

66. State v. Gibson, 69 N.D. 70, 99, 284 N.W. 209, 223 (1938). See also People v. Mones, 59 Philippine I. 46, 56-57 (1933).

67. United States v. Williams, 28 Fed. Cas. No. 16,707, at 644 (C.C.D. Me. 1858) ("Where the fact of death is fully proved by other evidence, no reason is perceived why the free and voluntary confession of the party, if deliberately made, may not be sufficient to establish the other element of the corpus delicti, provided it satisfactorily appears that other evidence does not exist.") ; Sam v. State, 33 Miss. 347, 353 (1857); State v. Potter, 52 Vt. 33 (1879). In Ausmus v. People, 47 Colo. 167, 180-81, 107 Pac. 204, 209-10 (1909), the court expressed its preference for a definition of corpus delicti including the injury only, but did not go so far as to base its decision on such a definition since there was sufficient evidence of criminality in the record. See discussion in People v. Ranney, 153 Mich. 293, 116 N.W. 999 (1908).

68. Forte v. United States, 94 F.2d 236, 243 (D.C. Cir. 1937) ("We think that this case decided in 1858 [United States v. Williams, supra note 67], does not represent the current rule upon the subject."); Pitts v. State, 43 Miss. 472 (1870) (no mention of Sam v. State, supra note 67, but held, corpus delicti of murder is death through criminal agency); State v. Longe, $96 \mathrm{Vt}$. 7, 116 At1. 81 (1922) (no mention of State v. Potter, supra note 67, but held, corpus delicti of murder is death through criminal agency).

69. Missourr : cf. State v. Bennett, 6 S.W.2d 881, 883 (Mo. 1928); State v. Joy, 315 Mo. 7, 285 S.W. 489 (1926) (No confession involved. The concurring opinion, however, discusses the effect of such a definition on cases involving confessions. Id. at 19, $285 \mathrm{~S}$.W. at 494.) Wigmore cites these two cases as standing for the three-element definition of corpus delicti. 7 WIGMORE, EvIDENCE 402-03, n.4 (3d ed. 1940). In State v. Hawkins, 165 S.W.2d 644, 646 (Mo. 1942), the court said: "[These cases] . . . do not add the third requirement, as Professor Wigmore suggests, of proof of the accused's identity or agency as the criminal. True the statement is made by the judge who wrote the opinion but in each instance the other two judges of the division specifically did not concur in that statement."

OnIo: State v. Leuth, 5 Ohio Cir. Ct. 94, 104-05 (1890) (cites Wharton, CRIMINAL Evidence $\$ 325$ (8th ed. 1880), which says that the corpus delicti consists of "(1) a criminal act; and (2) the defendant's agency in the production of such act"). Contra: State v. Wehr, 6 Ohio N.P. 345 (1899) (points out that later editions of Wharton, Criminal Evidence say corpus delicti does not include defendant's agency). OrEgon: See State v. Howard, 102 Ore. 431, 440, 203 Pac. 311, 314 (1921) (even if corpus delicti were considered to include defendant's agency, there is sufficient independent evidence thereof). Contra: State v. Henderson, 184 P.2d 392 (Ore. 1947). Texas: Ellison v. State, 59 Tex. Crim. Rep. 3, 127 S.W. 542 (1910); Josef v. State, 34 Tex. Crim. Rep. 446, 30 S.W. 1067 (1895) (no confession involved). Contra: Watson v. State, 154 Tex. Crim. Rep. 438, 227 S.W.2d 559 (1950).

70. 7 Wigmore, Evidence §2072(3) (3d ed. 1940). But see text following note 60 supra.

71. See text at note 63 and note 63 supra. 
to prove the corpus delicti without connecting the defendant with the crime. Among these would be drunken driving, ${ }^{72}$ illegal use of narcotics, any offense involving fraud, such as tax evasion, ${ }^{73}$ and any offense of which scienter is an element, such as transporting a car across a state line knowing it to be stolen ${ }^{74}$ or knowingly permitting the consumption of intoxicating beverages in one's restaurant without a license. ${ }^{75}$ But merely because proof of the corpus delicti, in effect, involves proof of the whole charge, the prosecution is not relieved from proving the corpus delicti aliunde the confession. ${ }^{76}$

There are many detailed elements of the prosecution's case which do not fit clearly into any of the categories of injury, criminality or defendant's agency. Whether these elements should be included in the corpus delicti and thus be included within the requirement of independent proof is a problem which has been troublesome in many cases. On the one hand, the courts do not want to deprive the defendant of the protection of the rule requiring independent proof of the crime, and, on the other hand, they do not want to make it impossible for the prosecution to prove its case.

There is some disagreement in the language of the decisions as to whether the identity of the deceased in a murder prosecution must be proved as part of the corpus delicti, aliunde the confession. ${ }^{77}$ No case has been found, however, the result of which has turned on the difference between the rules which the courts have enunciated. Obviously, the independent proof, in order to add anything to the confession, must be of the particular murder to which the defendant has confessed. ${ }^{78}$ The following examples will illustrate the different ways in which the independent proof of the corpus delicti may be linked to the defendant's confession.

(1) The defendant confesses that he murdered John Smith, and a dead body is found which witnesses examine and identify as John Smith. This is the most satisfactory means of identification.

72. State v. Jones, 108 A.2d 261 (Me. 1954).

73. Smith v. United States, 75 Sup. Ct. 194, 198 (1954).

74. Manning v. United States, 215 F.2d 945 (10th Cir. 1954) ; Forte v. United States, 94 F.2d 236, 244 (D.C. Cir.), on certified questions, 302 U.S. 220 (1937).

75. State v. Carter, 275 P.2d 847 (N.M. 1954).

76. See cases cited in notes $72-75$ supra.

77. The following cases support the rule that identification of the deceased is part of the corpus delicti: Edmonds v. State, 34 Ark. 720, 746-47 (1879); Wall v. State, 5 Ga. App. 305, 63 S.E. 27 (1908); Parker v. State, 228 Ind. 1, 88 N.E.2d 556 (1949), rehearing denied, 228 Ind. 1, 89 N.E.2d 442 (1950); State v. Weston, 102 Ore. 102, 118, 201 Pac. 1083, 1088 (1921); cf. State v. Howard, 102 Ore. 431, 203 Pac. 311 (1921) (conviction of assault reversed since victim not identified aliunde).

The following cases support the rule that identification of the deceased is not part of the corpus delicti : People v. Mondich, 234 Mich. 590, 208 N.W. 675 (1926) (slight evidence of identity present); see Smith v. Commonwealth, 21 Grat. 809, 818-19 (Va. 1871) (If defendant's confession is to be relied upon to prove identity, it ought to be certain that what he said was intended to be an admission that the body found was the same child who was delivered to him.) ; cf. State v. Riggs, 61 Mont. 25, 201 Pac. 272 (1921). See also 1 Wharton, Criminal Evidence $\$ 325$ (10th ed. 1912).

78. Accord, State v. Laliyer, 4 Minn. 368 (1860). 
(2) The defendant confesses that he murdered John Smith, and a dead body is found whose features are unrecognizable because of decomposition or destruction. Witnesses are able to recognize the clothes, teeth or hair of the deceased as those of John Smith. Where necessary, identification by such circumstantial evidence is allowed even in cases where there is no confession. ${ }^{79}$

(3) The defendant confesses that he murdered John Smith and buried him in a particular place in the woods. The police follow the directions of the defendant and find an unrecognizable body at that place. Proof of the deceased's name independent of the confession in this case should be unnecessary, since the fact that a body was found at the place the defendant described eliminates all but the slightest possibility that the body was not that of the defendant's victim. In contrast, if the defendant confessed that he had drowned his victim in a river and an unidentifiable body was found in the same river, there would not be sufficient identification of the deceased as the defendant's victim. It would be possible that the body was that of another person and that the defendant was mistaken in thinking that he had killed his victim; or it would be possible that the defendant had made a pathological confession. In either case the chance of coincidence in finding the body in the river is much greater than in finding the body in a secluded grave in a particular place in the woods.

(4) The defendant confesses that he murdered John Smith by shooting him three times in the back of the head, and an unrecognizable body is found with three bullet holes in the back of its head. In this case it should not be necessary to prove the name of the deceased aliunde the confession. The matching of the wounds on the body with the wounds that the defendant said he had inflicted on his victim is sufficient identification. As a practical matter, the police often reduce the danger of a false confession even more in cases similar to this by asking the confessor why he inflicted on the deceased several different types of wounds which in fact do not exist. ${ }^{80} \mathrm{~A}$ person who is determined for some reason to make a false confession is likely to admit having inflicted such wounds.

Courts generally have said that the manner in which the deceased was killed need not be proved aliunde the confession. ${ }^{81}$ But it would seem that such proof is essential to the extent necessary to show that the particular murder to which the defendant has confessed was committed, or to the extent necessary to show that the death of the deceased was criminally caused. In a case in which a skeleton is found buried in a shallow grave in a thicket, with no marker, and with lime in the grave, adequate proof of criminality aliunde the confession requires evidence of the manner in which

79. McVeigh v. State, 205 Ga. 326, 53 S.E.2d 462 (1949) ; Gray v. Commonwealth, $101 \mathrm{~Pa} 380$ (1882); Edmonds v. State, 34 Ark. 720,747 (1879).

80. See letter from James P. Kellstedt, State's Attorney, Peoria, Illinois, dated Jan. 3, 1955, on file in Biddle Law Library, University of Pennsylvania Law School.

81. McVeigh v. State, 205 Ga. 326, 340, 53 S.E.2d 462, 471 (1949); State v. Knapp, 70 Ohio St. 380, 71 N.E. 705 (1904); State v. Leuth, 5 Ohio Cir. Ct. 94 (1890). 
the deceased was killed. However, on these facts the Georgia Supreme Court inferred criminality from the apparent attempt to conceal the body. ${ }^{82}$ When a body is found with a crushed skull, proof that death was caused by a hammer rather than a hatchet would not necessarily be important, but proof that death was caused by a hammer rather than an automobile would be important.

A Delaware court has held that independent proof of malice aforethought is not requisite to conviction. 83 It would seem that better proof of the defendant's state of mind than his confession could not be offered, and to require additional evidence would impose an onerous burden on the prosecution, making conviction impossible in many cases in which the defendant is guilty. On the other hand, fear that the defendant was unaware, when he confessed to murder, of the legal distinction between murder and lesser types of homicide, ${ }^{84}$ would motivate a court to require independent proof of malice aforethought.

On the whole, the courts have not been very receptive to arguments that various detailed points must be proved independently. Conviction of adultery was affirmed in a case in which the defendant at trial denied only that part of his confession which stated that the adultery had been committed in the state in which he was being tried, and then argued that he could not be convicted unless jurisdiction was proved independently of his confession. The court pointed out that the purpose of the rule requiring extrinsic evidence of the crime was to prevent conviction for a crime which had not been committed, and that proof of jurisdiction would not further that purpose. ${ }^{85}$ Similarly, in a case in which an Indian was being prosecuted for the murder of a white man, the Supreme Court of the United States held that the fact that the burned body which had been found was that of a white man need not be proved as part of the corpus delicti independently of the defendant's statements, since the race of the deceased was material only to the question of jurisdiction and not to the question of whether a crime had been committed. ${ }^{86}$

Some of the detailed elements over which the courts struggle, however, are clearly requisite to the proof of either the basic injury or of criminality, and, therefore, should be included in the corpus delicti. For example, where the defendant confesses that he stole certain goods which are found in his possession, proof that the goods are missing from the victim's possession is essential to proof of the basic injury of larceny, and

82. McVeigh v. State, 205 Ga. 326, 53 S.E.2d 462 (1949). 1930).

83. State v. Galvana, 34 Del. (4 Harring) 409, 154 Atl. 461 (Ct. Oyer \& Ter.

84. See text at note 39 supra.

85. See Commonwealth v. Dolph, $164 \mathrm{~Pa}$. Super. 415, 420, 65 A.2d 253, 255 (1949); see also Commonwealth v. Marshall, 287 Pa. 512, 135 Atl. 301 (1926).

86. Isaacs v. United States, 159 U.S. 487 (1895). There was no identification problem in this case. In a case where such a problem did exist, however, the race of the deceased might be relevant to prove whether a crime had been committed. See text at and following note 77 supra. 
therefore should be included in the corpus delicti.87 Proof of the crime of conspiracy, unlike the proof of most crimes, is not clearly dissectible into the three main elements, but the agreement is basic to the injury and, therefore, should be included in the corpus delicti. ${ }^{88}$ Proof of the penetration in sodomy, ${ }^{89}$ of the felony in felony murder,,$^{90}$ of the scienter in transporting a stolen car across the state line knowing it to be stolen, ${ }^{91}$ of the intention to commit a felony in burglary, ${ }^{92}$ of the intention to steal at the time possession was obtained in larceny by trick, ${ }^{93}$ and of the operation of a truck at a negligent rate of speed in manslaughter ${ }^{94}$ are all essential to proof of criminality and, therefore, should be included in the corpus delicti. In Illinois, in order to constitute statutory rape the prosecutrix must be under sixteen and the defendant over seventeen. ${ }^{95}$ The Illinois Supreme Court correctly held that the age of the defendant is part of the corpus delicti of statutory rape, but it misapplied the rule, holding that the defendant's appearance was not sufficient proof of his age since it could not be preserved in the record for review by the appellate court. ${ }^{96}$ This might make sense where there is a close question as to the defendant's age, but in this case the defendant had confessed that he was thirty-five.

At least two courts have held that those details which merely increase the degree of the crime are not included in the corpus delicti, while those details which make otherwise non-criminal actions criminal are included..$^{97}$ Accordingly, the Missouri Supreme Court held that the fact that the theft was in the night time was not part of the corpus delicti of larceny in the night time, ${ }^{88}$ and in another case said that the fact that the theft was from a dwelling house was not part of the corpus delicti of larceny from a dwelling house. $^{99}$ This rule would be of greater aid to the prosecution in the first type of case than in the second, for ordinarily it would be easier to prove that goods were stolen from a particular place than to prove that they were stolen at a particular time.

87. Accord, People v. Maruda, 314 I11. 536, 145 N.E. 696 (1924) ; Commonwealth v. Gold, 155 Pa. Super. 364, 38 A.2d 486 (1944).

88. Accord, Tingle v. United States, 38 F.2d 573 (8th Cir. 1930); Short v. People, 27 Colo. 175, 60 Pac. 350 (1900).

89. Accord, United States v. Kelly, 119 F. Supp. 217 (D.D.C. 1954).

90. Accord, People v. Giusto, 206 N.Y. 67, 99 N.E. 190 (1912). But cf. State v. Leuth, 5 Ohio Cir. Ct. 94 (1890).

91. Accord, Manning v. United States, 215 F.2d 245 (10th Cir. 1954); United States v. Angel, 201 F.2d 531 (7th Cir. 1953); Forte v. United States, 94 F.2d 236

(D.C. Cir. 1937); Whitehead v. State, 16 Ala. App. 427, 78 So. 467 (1918).

92. Accord, Brown v. State, 85 Miss. 27, 37 So. 497 (1904).

93. Accord, State v. Blay, 77 Vt. 56, 58 Atl. 794 (1904).

94. Accord, Ercoli v. United States, 131 F.2d 354 (D.C. Cir. 1942).

95. Ill. Ann. Stat. c. $38, \S 490$ (1934).

96. People v. Rogers, 415 I11. 343, 114 N.E.2d 398 (1953).

97. Forte v. United States, 94 F.2d 236, 243 (D.C. Cir.), on certified questions,

302 U.S. 220 (1937); State v. McGuire, 327 Mo. 1176, 39 S.W.2d 523 (1931).

98. State v. McGuire, 327 Mo. 1176, 39 S.W.2d 523 (1931).

99. State v. Flowers, 311 Mo. 510, 278 S.W. 1040 (1925). 


\section{Independent Proof of the Corpus Delicti}

Most jurisdictions require independent proof of the corpus delicti; 100 this gives rise to three main problems: (1) Must each element of the corpus delicti be independently proved? If not, to what extent may the confession be used? (2) What quantum of independent proof is required? and (3) How significant is the charge to the jury?

\section{Extent to Which Proof of the Corpus Delicti Must Be Independent of the Confession}

Some courts require that proof of the corpus delicti be completely independent of the defendant's confession, ${ }^{101}$ while others allow the confession to be used to fill in gaps in the independent proof by lending significance to otherwise unimportant facts. ${ }^{102}$ For example: $X$ 's body was found

100. See cases cited in notes 101, 102 infra.

101. Alabama: Hines v. State, 260 Ala. 668, 72 So.2d 296 (1954); Peoples v. State, 256 Ala. 612, 56 So.2d 665 (1952); Rutland v. State, 31 Ala. App. 43, 11 So.2d 768 (1943) ; Braxton v. State, 17 Ala. App. 167, 82 So. 657 (1919). CalrForNIA: People v. Kinder, 122 Cal. App.2d 457, 265 P.2d 24 (1954); People v. Holman, 72 Cal. App.2d 75, 164 P.2d 297 (1945) ; People v. Monks, 133 Cal. App. 440, 24 P.2d 508 (1933) ; People v. Hayes, 72 Cal. App. 292, 301, 237 Pac. 390, 394 (1925). ConNeCtICUT: State v. Guastamachio, 137 Conn. 179, 75 A.2d 429 (1950). Contra: State v. La Louche, 116 Conn. 691, 166 Atl. 252 (1933). Florma: McElveen v. State, 72 So.2d 785 (Fla. 1954); Parrish v. State, 90 Fla. 25, 105 So. 130 (1925) ; Holland v. State, 39 Fla. 178, 22 So. 298 (1897). GEorgIA: Grimes v. State, 204 Ga. 854, 51 S.E.2d 797 (1949); Clay v. State, 176 Ga. 403, 168 S.E. 289 (1933) ; Grimes v. State, 79 Ga. App. 489, 54 S.E.2d 302 (1949). Contra: Logue v. State, 198 Ga. 672, 32 S.E.2d 397 (1944). INDIANA: Dennis v. State, 230 Ind. 210, 102 N.E.2d 650 (1952) ; Parker v. State, 228 Ind. 1, 88 N.E.2d 556 (1949), rehearing denied, 89 N.E.2d 442 (1950). MaINE: State v. Carleton, 148 Me. 276, 92 A.2d 327 (1952) ; State v. Hoffses, 147 Me. 221, 85 A.2d 919 (1952). Mrchigan: People v. Coapman, 326 Mich. 321, 40 N.W.2d 167 (1949). MississippI: Pope v. State, 158 Miss. 794, 131 So. 264 (1930). MontanA: State v. Ratkovich, 111 Mont. 9, 105 P.2d 679 (1940). New Mexico: State v. Lindemuth, 56 N.M. 257, 243 P.2d 325 (1952). But see State v. Chaves, 27 N.M. 504, 507, 202 Pac. 694, 695 (1921) (The court said that there was sufficient evidence of the corpus delicti without reference to the confession; therefore, it was unnecessary to determine whether the confession could have been used as an aid in proving it.). ORLAHOMA: Osborn v. State, 86 Okla. Cr. 259, 194 P.2d 176 (1948). Pennsylvania: Commonwealth v. Bishop, 285 Pa. 49, 131 Atl. 657 (1926) ; Gray v. Commonwealth, 101 Pa. 380 (1882); Commonwealth v. Du Hadway, 175 Pa. Super. 201, 103 A.2d 489 (1954). Soutr Carolina: State v. Thomas, 222 S.C. 484,73 S.E.2d 722 (1952); State v. Miller, 211 S.C. 306, 45 S.E.2d 23 (1947). TeNNEsseE: Taylor v. State, 191 Tenn. 670, 235 S.W.2d 818 (1950), cert. denied, 340 U.S. 918 (1951); Ashby v. State, 124 Tenn. 684, 139 S.W. 872 (1911). FEDERAL: United States v. Angel, 201 F.2d 531 (7th Cir. 1953); Tingle v. United States, 38 F.2d 573 (8th Cir. 1930); Manning v. United States, 215 F.2d 945 (10th Cir. 1954); Forte v. United States, 94 F.2d 236 (D.C. Cir.), on certified questions, 302 U.S. 220 (1937); cf. Smith v. United States, 75 Sup. Ct. 194 (1954).

102. ArRansas: Mouser v. State, 216 Ark. 965, 228 S.W.2d 472 (1950); Hall v. State, 209 Ark. 180, 189 S.W.2d 917 (1945); Hubbard v. State, 77 Ark. 126, 91 S.W. 11 (1905); Misenheimer v. State, 73 Ark. 407, 84 S.W. 494 (1904). Dezaware: State v. Kehm, 103 A.2d 781 (Del. Super. Ct. 1954). IDAmo: State v. Keller, 8 Idaho 699, 70 Pac. 1051 (1902). Illinors: People v. Gavurnik, 2 Ill.2d 190, 117 N.E.2d 782 (1954); People v. Harrison, 261 Ill. 517, 104 N.E. 259 (1914). IowA: State v. Wescott, 130 Iowa 1, 104 N.W. 341 (1905). Maryland: Davis v. State, 202 Md. 463, 97 A.2d 303 (1953). Mrnnesota: State v. Laliyer, 4 Minn. 368 (1860). Mrssounr: State v. Knowles, 185 Mo. 141, 83 S.W. 1083 (1904). Nebraska: Gallegos v. State, 152 Neb. 831, 43 N.W.2d 1 (1950). Nevada: In re 
buried in an obscure place, and the defendant confessed that he had murdered him, describing in detail the way in which $X$ had been buried. A blood stain was found on the floor where the defendant said that he had beaten $X$ to death. This was held to be sufficient evidence of the corpus delicti when considered in connection with the confession. ${ }^{103}$ However, discounting the confession, there would not be sufficient evidence of the corpus delicti. The blood stain on the floor is of little significance without the defendant's confession that he beat the deceased to death at that place. The Georgia Supreme Court, in rejecting the idea that the confession be used to help prove the corpus delicti, said: "To accept the existence of facts drawn from a confession to be the basis of the corpus delicti would be to let a portion of the confession corroborate itself." 104 But in every jurisdiction, with the exception of Pennsylvania, ${ }^{105}$ the confession may be used at least as cumulative evidence of the corpus delicti, ${ }^{108}$ i.e., once sufficient independent evidence of the corpus delicti has been introduced, the confession may be added thereto to help convince the jury beyond a reasonable doubt that the crime has been committed. Although most courts say that independent proof of the corpus delicti should precede the introduction of the confession, ${ }^{107}$ a reversal of the order of proof, provided sufficient inde-

Kelley, 28 Nev. 491, 83 Pac. 223 (1905). NEw York: People v. Badgley, 16 Wend. 53 (N.Y. 1836). OتIo: State v. Knapp, 70 Ohio St. 380, 71 N.E. 705 (1904). Rhode Island: State v. Jacobs, 21 R.I. 259, 43 Atl. 31 (1899). Texas: Sims v. State, 91 Tex. Crim. Rep. 570, 239 S.W. 1116 (1922); Ingram v. State, 78 Tex. Crim. Rep. 559, 182 S.W. 290 (1916). VIRGINIA: Wheeler v. Commonwealth, 192 Va. 665,66 S.E.2d 605 (1951); Cleek v. Commonwealth, 165 Va. 697, 181 S.E. 359 (1935). Washington: State v. Van Brunt, 22 Wash.2d 103, 154 P.2d 606 (1944); State v. Scott, 86 Wash. 296, 150 Pac. 423 (1915). West VIRGINIA: State v. Blackwell, 102 W. Va. 421, 135 S.E. 393 (1926); State v. Hall, 31 W. Va. 505, 7 S.E. 422 (1888). Wyoming: Curran v. State, 12 Wyo. 553, 76 Pac. 577 (1904). FEDERAL: Bell v. United States, 185 F.2d 302 (4th Cir. 1950), cert. denied, 340 U.S. 930 (1951); Vogt v. United States, 156 F.2d 308 (5th Cir. 1946); of. Opper v. United States, 75 Sup. Ct. 158 (1954).

103. Gallegos v. State, 152 Neb. 831, 43 N.W.2d 1 (1950).

104. Clay v. State, $176 \mathrm{Ga} .403,405,168$ S.E. 289, 290 (1933). This case was specifically overruled on this point by Logue v. State, $198 \mathrm{Ga} .672,675,32$ S.E.2d 397, 399 (1944), but Grimes v. State, 79 Ga. App. 489, 54 S.E.2d 302 (1949), apparently cited the Logue case for the very proposition which that case had supposedly overruled.

105. See text at and following note 192 infra.

106. Forte v. United States, 94 F.2d 236 (D.C. Cir.), on certified questions, 302 U.S. 220 (1937) ; People v. Roganovich, 77. Cal. App. 158, 246 Pac. 132 (1926); McVeigh v. State, 205 Ga. 326, 53 S.E.2d 462 (1949); State v. Carleton, 148 Me. 237, 92 A.2d 327 (1952); State v. Ratkovich, 111 Mont. 9, 105 P.2d 679 (1940); Ashby v. State, 124 Tenn. 684, 139 S.W. 872 (1911); State v. Lutes, 38 Wash.2d 475, 230 P.2d 786 (1951). See also cases cited in notes 113-15 infra, from which this proposition can be implied.

107. Alabama: Hines v. State, 260 Ala. 668, 72 So.2d 296 (1954); Peoples v. State, 256 Ala. 612, 56 So.2d 665 (1952); Rutland v. State, 31 Ala. App. 43, 11 So.2d 768 (1943) ; Daniels v. State, 12 Ala. App. 119, 68 So. 499 (1915); Granison v. State, 117 Ala. 22, 23 So. 146 (1898). ArIzona: State v. Romo, 66 Ariz. 174, 185 P.2d 757 (1947). CariforniA: People v. Kinder, 122 Cal. App.2d 457, 265 P.2d 24 (1954); People v. Holman, 72 Cal. App.2d 75, 164 P.2d 297 (1945); People v. Monks, 133 Cal. App. 440, 24 P.2d 508 (1933) ; People v. Hayes, 72 Cal. App. 292, 237 Pac. 390 (1925) ; People v. Swaile, 12 Cal. App. 192, 107 Pac. 134 (1909). Connecticut: State v. Guastamachio, 137 Conn. 179, 75 A.2d 429 (1950). Florma: McElveen v. State, 72 So.2d 785 (Fla. 1954); Parrish v. State, 90 Fla. 25, 105 So. 130 (1925); Holland v. State, 39 Fla. 178, 22 So. 298 (1897). GeorgIA: 
pendent proof is introduced at some point, does not constitute reversible error. ${ }^{108}$

There are certain dangers inherent in a rule which permits the confession to be used to help prove the corpus delicti. One psychologist maintains that knowledge of a confession produces powerful suggestive influences for judges, witnesses, experts, and all concerned in the case. The human mind is so inclined to adapt everything perceived to some given explanation that it strains for an explanation and trims facts until they fit easily into that explanation.

"We hear of a certain crime and consider the earliest data. For one reason or another we begin to suspect $A$ as the criminal. The result of an examination of the premises is applied in each detail to this proposition. It fits. So does the autopsy, so do the depositions of witnesses. Everything fits. There have indeed been difficulties, but they have been set aside, they are attributed to inaccurate observation and the like,-the point is,-that this evidence is against A. Now, suppose that $B$ confesses the crime; this event is so significant that it sets aside at once all the earlier reasons for suspecting $A$, and the theory of the crime involves $B$. Naturally the whole material must now be applied to $B$, and in spite of the fact that it at first fitted $A$, it does now fit $B$. Here again difficulties arise, but they are to be set aside just as before." 100

Although it would be impossible to eliminate this danger completely, the risk can be minimized by requiring that the corpus delicti be proved without the aid of the defendant's confession, and that the confession not be admitted until the requirement of independent proof is satisfied.

McVeigh v. State, 205 Ga. 326, 53 S.E.2d 462 (1949); Grimes v. State, 204 Ga. 854,51 S.E.2d 797 (1949); Clay v. State, 176 Ga. 403, 168 S.E. 289 (1933); Grimes v. State, 79 Ga. App. 489, 54 S.E.2d 302 (1949). InDIANA: Parker v. State, 228 Ind. 1,88 N.E.2d 556 (1949), rehearing denied, 228 Ind. 1,89 N.E.2d 442 (1950). Marne: State v. Carleton, 148 Me. 237, 92 A.2d 327 (1952); State v. Hoffses, 147 Me. 221,85 A.2d 919 (1952). MichIGAN : People v. Coapman, 326 Mich. 321, 40 N.W.2d 167 (1949). Minnesota: State v. Laliyer, 4 Minn. 368 (1860); but see State v. Grear, 29 Minn. 221, 13 N.W. 140 (1882). OHro: State v. Arnold, 63 N.E.2d 31 (Ohio Ct. App. 1945). Pennsxlvania: Gray v. Commonwealth, $101 \mathrm{~Pa} .380$ (1882). Soutr Carolina: State v. Miller, 211 S.C. 306, 45 S.E.2d 23 (1947). TENNESSEE: Taylor v. State, 191 Tenn. 670, 235 S.W.2d 818 (1950), cert. denied, 340 U.S. 918 (1951); Ashby v. State, 124 Tenn. 684, 139 S.W. 872 (1911). UTAH: State v. Johnson, 95 Utah 572, 83 P.2d 1010 (1938).

108. People v. McWilliams, 117 Cal. App. 732, 4 P.2d 601 (1931); People v. Swaile, 12 Cal. App. 192, 107 Pac. 134 (1909); Williams v. People, 114 Colo. 207, 158 P.2d 447 (1945) ; Parrish v. State, 90 Fla. 25, 105 So. 130 (1925) ; Parker v. State, 228 Ind. 1, 88 N.E.2d 556 (1949), rehearing denied, 89 N.E.2d 442 (1950); State v. Grear, 29 Minn. 221, 13 N.W. 140 (1882); State v. James, 96 N.J.L. 132, 114 At1. 553 (1921); Commonwealth v. Lettrich, 346 Pa. 497, 31 A.2d 155 (1943); Taylor v. State, 191 Tenn. 670, 235 S.W.2d 818 (1950), cert. denied, 340 U.S. 918 (1951).

109. Gross, Criminal Psychology 33 (1911). 


\section{Quantum of Independent Proof Required}

There are many different formulations of the necessary quantum of independent evidence of the corpus delicti. Pennsylvania is the only jurisdiction requiring that the corpus delicti be proved beyond a reasonable doubt without using the confession, ${ }^{110}$ although some other jurisdictions formerly imposed a like requirement. ${ }^{111}$ But since the confession is admitted after prima facie independent proof has been introduced, it seems rather unrealistic to charge the jury that, disregarding the confession, they must be convinced of the corpus delicti beyond a reasonable doubt. The Mississippi Supreme Court has stated that the corpus delicti must be independently proved by a preponderance of the evidence.112 The remaining jurisdictions may be divided into three main groups: (1) those requiring prima facie independent proof of the corpus delicti, ${ }^{113}$ (2) those requiring some quantum of independent evidence less than prima facie, ${ }^{114}$ and (3)

110. See text at note 193 infra.

111. See Harden v. State, 109 Ala. 50, 19 So. 494 (1896), not followed in Braxton v. State, 17 Ala. App. 167, 82 So. 657 (1919); cf. State v. Benham, 58 Ariz. 129, 140, 118 P.2d 91, 95 (1941), explained in State v. Romo, 66 Ariz. 174, 18788, 185 P.2d 757, 766 (1947).

112. Roberts v. State, 210 Miss. 777, 50 So.2d 356 (1951) ; Pope v. State, 158 Miss. 794, 131 So. 264 (1930). But cf. Buford v. State, 69 So.2d 826 (Miss. 1954) (any corroborative evidence is sufficient which satisfies the mind that the crime is real and not imaginary); Garner v. State, 132 Miss. 815, 96 So. 743 (1923) (much slighter proof of the corpus delicti is required where there is a confession).

113. Alabama: Granison v. State, 117 Ala. 22, 23 So. 146 (1898); Winslow v. State, 76 Ala. 42 (1884); Rutland v. State, 31 Ala. App. 43, 11 So.2d 768 (1943); Braxton v. State, 17 Ala. App. 167, 82 So. 657 (1919); Whitehead v. State, 16 Ala. App. 427, 78 So. 467 (1918). But cf. Daniels v. State, 12 Ala. App. 119, 121, 68 So. 499 (1915) ("any evidence at all, even the slightest tendency") ; Harden v. State, 109 Ala. 50, 19 So. 494 (1896) (beyond a reasonable doubt), not followed int Braxton v. State, supra. California: People v. Kinder, 122 Cal. App.2d 457, 265 P.2d 24 (1954); People v. Day, 71 Cal. App.2d 1, 161 P.2d 803 (1945) ; People v. Hudson, 139 Cal. App. 165, 4 P.2d 809 (1934) ("slight or prima facie evidence"); People v. Monks, 133 Cal. App. 440, 24 P.2d 508 (1933) ; People v. Roganovich, 77 Cal. App. 158, 246 Pac. 132 (1926); People v. Hayes, 72 Cal. App. 292, 237 Pac. 390 (1925). ConNeCTICut: State v. Guastamachio, 137 Conn. 179, 182, 75 A.2d 429, 430 (1950) (evidence of a "substantial character"). FrorIDA: McElveen v. State, 72 So.2d 785 (Fla. 1954) ; Parrish v. State, 90 Fla. 25, 105 So. 130 (1925); Holland v. State, 39 Fla. 178, 22 So. 298 (1897). Georgia: McVeigh v. State, 205 Ga. 326, 53 S.E.2d 462 (1949); Grimes v. State, 79 Ga. App. 489, 54 S.E.2d 302 (1949). Indrana : Dennis v. State, 230 Ind. 210, 216, 102 N.E.2d 650, 653 (1952) ("clear proof"). MaINe: State v. Carleton, 148 Me. 237, 92 A.2d 327 (1952) (evidence giving rise to a reasonable inference of the existence of the corpus delicti); State v. Hoffses, 147 Me. 221, 85 A.2d 919 (1952) (same). MichigaN : People v. Coapman, 326 Mich. 321, 40 N.W.2d 167 (1949). But cf. People v. Ranney, 153 Mich. 293, 116 N.W. 999 (1908) ("some evidence"). NEw MExico: State v. Lindemuth, 56 N.M. 257, 243 P.2d 325 (1952); State v. Chaves, 27 N.M. 504, 202 P.2d 694 (1921). North Carolina: State v. Cope, 81 S.E.2d 773 (N.C. 1954). Tennessee: Taylor v. State, 191 Tenn. 670, 235 S.W.2d 818 (1950), cert. denied, 340 U.S. 918 (1951); Ashby v. State, 124 Tenn. 684, 139 S.W. 872 (1911). 'WAsHington: State v. Lutes, 38 Wash.2d 475, 230 P.2d 786 (1951); State v. Meyer, 37 Wash.2d 759, 226 P.2d 204 (1951).

114. ARRansas: Mouser v. State, 216 Ark. 965, 228 S.W.2d 472 (1950). IDAHo: State v. Downing, 23 Idaho 540, 130 Pac. 461 (1913) ; State v. Keller, 8 Idaho 699 , 70 Pac. 1051 (1902). Maryland: Weller v. State, 150 Md. 278, 132 At1. 624 (1926). Minnesora: State v. Laliyer, 4 Minn. 368 (1860). Missoun: State v. Thompson, 333 Mo. 1069, 64 S.W.2d 277 (1933); State v. McGuire, 327 Mo. 1176, 39 S.W.2d 523 (1931). Nebraska: Gallegos v. State, 152 Neb. 831, 43 N.W.2d 1 (1950). 
those which do not lay down an inflexible rule but rather decide each case separately. ${ }^{115}$

The difference between many of these versions of the rule requiring independent evidence often is mainly one of language. For example, assuming a requirement that there be proof of the corpus delicti completely independent of the defendant's confession, there is, except in a rare case, only a minute difference between requiring prima facie proof and some measure less than prima facie proof. Similarly, there is seldom any difference between requiring that there be "substantial" independent proof of the corpus delicti and that there be "some" independent proof.

Certain evidence which normally is inadmissible is not wholly valueless logically, for example, hearsay and evidence which is held legally irrelevant because of the danger that it will raise collateral issues or unduly prejudice the defendant. To compensate for the burden imposed on the prosecution of, in effect, proving the corpus delicti twice, once independently and once through the confession, it might be thought that the rules governing the admissibility of evidence would be relaxed somewhat in the first instance. It seems fairly well settled, however, that courts will not allow otherwise incompetent evidence to help fulfill the required

Nevada: In re Kelly, 28 Nev. 491, 83 Pac. 223 (1905). Rhode Istand: State v. Jacobs, 21 R.I. 259 (1899). Soutr Carolina: State v. Blocker, 205 S.C. 303, 31 S.E.2d 908 (1944). But see State v. Thomas, 222 S.C. 484,73 S.E.2d 722 (1952) (court implies that prima facie proof required). Vermont: State v. Blay, $77 \mathrm{Vt}$. 56, 58 At1. 794 (1904). VIRGINIA : Campbell v. Commonwealth, 194 Va. 825, 75 S.E.2d 468 (1953); Cleek v. Commonwealth, 165 Va. 697, 181 S.E. 359 (1935). WEST VIRGINIA: State v. Blackwell, 102 W.Va. 421, 135 S.E. 393 (1926).

115. Arizona: State v. Romo, 66 Ariz. 174, 185 P.2d 757 (1947) (must have "reasonable proof" of the corpus delicti aliunde). Deraware: State v. Kehm, 103 A.2d 781, 782 (Del. Super. 1954) ("I understand the better reasoned cases to hold that the quantum of proof aliunde should be that which, though not in itself conclusive, when taken in connection with the confession, establishes the corpus delicti beyond a reasonable doubt."). Kansas: State v. Cardwell, 90 Kan. 606, 135 Pac. 597 (1913) (the independent evidence plus the confession must establish the corpus delicti beyond a reasonable doubt). Montana: State v. Ratkovich, 111 Mont. 9, 105 P.2d 679 (1940) (some independent evidence which together with the confession will establish the corpus delicti beyond a reasonable doubt). OHIo: State v. Maranda, 94 Ohio St. 364, 114 N.E. 1038 (1916) (Ohio courts have not attempted to set the quantum of extrinsic proof needed; it need not be beyond a reasonable doubt or even prima facie; there must be some proof, not necessarily direct, but usually circumstantial, tending to prove the fact that the crime was committed.); State v. Arnold, 63 N.E.2d 31 (Ohio Ct. App. 1945) (some evidence). OkLahoma: Ridinger v. State, 267 P.2d 175 (Okla. Crim. App. 1953); Leeks v. State, 95 Okla. Cr. 326, 245 P.2d 764 (1952) ; Osborn v. State, 86 Okla. Cr. 259, 194 P.2d 176 (1948). OreGoN : State v. Howard, 102 Ore. 431, 203 Pac. 311 (1921); State v. Weston, 102 Ore. 102, 201 Pac. 1083 (1921). Wyoming: Curran v. State, 12 Wyo. 553, 562, 76 Pac. 577, 578 (1904) ("such extrinsic corroborating circumstances as will, in connection with the confession, show the prisoner's guilt beyond a reasonable doubt"). FEDERAL: 4th Cir.: Bell v. United States, 185 F.2d 302, 309 (4th Cir. 1950), cert. denied, 340 U.S. 930 (1951) ("substantial evidence of the crime"). 8th Cir.: Gulotta v. United States, 113 F.2d 683, 685-86 (8th Cir. 1940) ("a substantial showing which together with the defendant's confession or admission establishes the crime beyond a reasonable doubt. . . . [There must be] independent proof of the corpus delicti, however slight such proof may be."). 10th Cir.: Manning v. United States, 215 F.2d 945, 952 (10th Cir. 1954) (evidence must fairly and reasonably show the elements of the corpus delicti). D.C. Cir.: Forte v. United States, 94 F.2d 236 (D.C. Cir.), on certified questions, 302 U.S. 220 (1937) ("substantial evidence"). 
quantum of independent proof of the corpus delicti. ${ }^{118}$ Where the defendant confessed that he had had incestuous relations with his daughter, and the daughter admitted the fact before trial but repudiated the statement at trial, conviction was reversed on the ground that her prior inconsistent statement could serve only as impeachment of her credibility, not as substantive proof that the crime had been committed. ${ }^{117}$ Likewise, conviction of sodomy was reversed where the only proof of the corpus delicti independent of the defendant's confession was the hearsay statement of the three-year-old alleged victim, who did not testify at the trial.118

Variations in the Requirement of Proof Depending on the Nature of the Crime.-Certain crimes, by nature, afford less evidence of either the basic injury or of criminality than do most crimes. ${ }^{119}$ The body is seldom recovered when murder is committed on the high seas, and unless there was an eye-witness to the crime there would be no direct proof of either element of the corpus delicti. In a case of infanticide, the body, because of its small size, is often disposed of without a trace, and because of the helplessness of the infant and the ease with which it can be killed there is rarely any direct or strong circumstantial evidence of the criminality. As a matter of fact, it is often possible for an unmarried mother, the most frequent perpetrator of this crime, to conceal the fact that the baby was ever born. In some instances, crimes such as incest and sodomy have no "victim" since the actions of both of the parties who participate in the offense are voluntary; and there are no lasting physicial manifestations of the crime comparable to the dead body in murder or the burned building in arson..$^{20}$ Consequently, proof of the corpus delicti of these crimes is very difficult.

Some courts have consciously recognized the problem by holding that the best evidence obtainable in view of the nature of the crime is all that is required in addition to the defendant's confession. ${ }^{121}$ Other courts, although they do not articulate a rule of this type, out of necessity seem to accept less independent proof of the corpus delicti in prosecutions for crimes which by their nature would afford less evidence. ${ }^{122}$ On the other

116. See cases cited in notes 117, 118 infra. But cf. Benjamin v. State, 274 S.W.2d 402 (Tex. Crim. App. 1955) (testimony of an accomplice plus defendant's confession sufficient to prove the corpus delicti without any independent evidence). 117. State v Cope, 81 S.E.2d 773 (N.C. 1954); see also, Commonwealth v. Kimball, 321 Mass. 290, 73 N.E.2d 468 (1947) ; Cohron v. State, 156 Tex. Crim. Rep. 331, 242 S.W.2d 776 (1951).

118. Pepoon v. Commonwealth, 192 Va. 804,66 S.E.2d 854 (1951); State v. Ferry, 275 P.2d 173 (Utah 1954).'But cf. People v. Korak, 303 I11. 438, 135 N.E. 764 (1922).

119. Wharton, Criminal Law 286 (2d ed. 1852).

120. The court used this analysis in Bergen v. People, 17 I11. 426 (1856) (conviction reversed since there was no independent evidence whatsoever).

121. United States v. Williams, 28 Fed. Cas. 636, No. 16,707 (1st Cir. 1858); State v, Romo, 66 Ariz. 174, 185 P.2d 757 (1947) ; State v. Cardwell, 90 Kan. 606, 135 Pac. 597 (1913); cf. United States v. Gilbert, 2 Sumn. 19, 27 (U.S. Cir. Ct. 1834).

122. Williams v. People, 114 Colo. 207, 158 P.2d 447, 452 (1945) (conviction of infanticide affirmed; no extrinsic evidence that the child had had independent life or that death was criminally caused; see dissenting opinion); Warmke v. Common- 
hand, North Carolina recognizes the problem but maintains that the same standard of independent proof must be met in every case, even where the corpus delicti is extremely difficult to prove. ${ }^{123}$

\section{Less Proof Required of Criminality than of the Basic Injury.-In} many types of cases involving confessions, although there is often direct proof of the basic injury, it is very difficult to prove aliunde that the injury was the result of a criminal, rather than a natural or accidental, cause. ${ }^{124}$ This is especially true in those murder cases where the death has been undiscovered for years and, therefore, the body is in an advanced state of decomposition, or in arson cases, where any potential evidence is usually destroyed in the fire itself. Although only two courts have specifically stated that less proof of the criminality is required than of the basic injury, ${ }^{125}$ examination of the facts of cases in which the body was not found for a number of years after death or in which all the evidence was consumed in the fire indicates clearly that several other courts of necessity adhere to such a rule. ${ }^{128}$

It is not difficult to imagine how this relaxation of the requirement of independent proof of the criminality developed. In the cases which prompted some courts to establish the corpus delicti rule, the wrongful convictions would not have taken place if proof of death had been required independent of the defendant's confession. The courts may have been anticipating the need for independent proof of the criminality, but their immediate concern was with proof of the basic injury.

wealth, 297 Ky. 649, 180 S.W.2d 872 (1944) (Prosecution for manslaughter; defendant stated that she accidentally had dropped her illegitimate infant from a trestle. Although the body never was recovered, the court held that evidence that the creek under the trestle was flooded, that a baby cap was found near the creek, that the defendant had not dropped the coat in which the baby was wrapped, and that the defendant had not reported the loss of the child was sufficient independent proof that the baby was dead and that death was criminally caused. The court did not indicate that it was consciously requiring less proof of the corpus delicti than in any other case.); Commonwealth v. Lettrich, $346 \mathrm{~Pa} .497,31$ A.2d 155 (1943) (Conviction of infanticide affirmed; defendant had confessed to smothering her sister's eight-dayold illegitimate child and burning its body in a furnace; the body never was found. There was independent evidence - that defendant had left the hospital with the child, that the child was normal and healthy, that the child was not capable of moving about or surviving without frequent nourishment, that defendant had assumed responsibility for the child's care, and that defendant had made several false statements as to the child's whereabouts. The appellate court held this to be sufficient evidence, without considering the confession, to support a jury finding that, beyond a reasonable doubt, the child was dead and its death was criminally caused.).

123. State v. Cope, 81 S.E.2d 773 (N.C. 1954).

124. This problem is not confined to cases involving confessions. As a matter of fact, the problem is even greater where the prosecution must prove the corpus delicti without the aid of a confession.

125. Edmonds v. State, 34 Ark. 720 (1879) (murder); see also McVeigh v. State, 205 Ga. 326, 53 S.E.2d 462 (1949) (murder). Although Alabama requires prima facie proof of the corpus delicti aliunde the confession, see note 113 supra, in Daniels v. State, 12 Ala. App. 119, 121, 68 So. 499 (1915), the court said that "any evidence at all, even the slightest tendency, that the burning was by design" would be sufficient. Conviction was reversed, however, since there was no evidence at all. 30 infra.

126. Ezell v. State, 217 Ark. 94, 229 S.W.2d 32 (1950); cases cited in notes 127- 
In a case in which the defendant confessed that he had murdered the deceased with his hands and pointed out the place where a skeleton identified as the deceased was found, the court accepted evidence that the deceased had been in good health immediately before her disappearance as sufficient independent proof of criminality. ${ }^{127}$ In another case where the defendant confessed that he had murdered the deceased, the only independent evidence of murder was the body and the testimony of a witness that he had heard a woman scream one night near the place where the body was found. Conviction was affirmed although there was no evidence connecting the scream with the time of the deceased's death. ${ }^{128}$ In an Illinois case in which the defendant confessed that he had burned a school building, there was evidence that footprints leading to and from the burned building matched those of defendant and were made at approximately the time of the fire, and also evidence that the defendant had been discharged from the school board shortly before. The court accepted this as sufficient independent proof that the burning was wilful. ${ }^{129}$ In State v. Blocker ${ }^{130}$ the Supreme Court of South Carolina, which ordinarily requires proof of the corpus delicti completely independent of the confession, ${ }^{131}$ accepted the elimination of other possible causes of burning as sufficient independent proof of wilfulness. An interesting comparison can be made between these cases, in which there was clear proof of the basic injury, and State $v$. Levesque, ${ }^{132}$ in which there was a reversal of a conviction of arson by the Maine Supreme Court because there was not clear proof that any part of the building had burned, the evidence showing only that some rubbish in the cellar had been consumed.

As a practical matter, the rule that less proof is required of the criminality than of the basic injury can be said to exist in every jurisdiction which enunciates a requirement of only slight proof of both elements of the corpus delicti. Since normally there is indisputable evidence of the basic injury, ${ }^{133}$ the advantage to the prosecution of having to produce only slight proof actually is effective only with respect to the criminality.

127. Hall v. State, 209 Ark. 180, 189 S.W.2d 917 (1945).

128. Gantling v. State, 41 Fla. 587,26 So. 737 (1899).

129. People v. Hannibal, 259 I11. 512, 102 N.E. 1042 (1913); see also Winslow v. State, 76 Ala. 42 (1884); Granison v. State, 117 Ala. 22, 23 So. 146 (1898); State v. Guastamachio, 137 Conn. 179, 75 A.2d 429 (1950); State v. Rogoway, 45 Ore. 601,78 Pac. 987 (1904), reversed on other grounds on rehearing, 45 Ore. 601 , 81 Pac. 234 (1905).

130. 205 S.C. 303, 31 S.E.2d 908 (1944).

131. See South Carolina cases cited in note 101 supra.

132. $146 \mathrm{Me}$.351, 81 A.2d 665 (1951).

133. But cf. State v. Lamb, $28 \mathrm{Mo} .218$ (1859), in which defendant confessed that he and his wife had checked into a certain hotel on a certain day, that they had quarreled, that they had walked to a nearby river, and that he had drowned her. All details of the confession, except what transpired between the time the couple left for the river and the time he returned, were supported by testimony of witnesses. No body was ever found. The appellate court affirmed conviction of murder in the first degree on the ground that confessions in court do not require independent proof, adding that there was sufficient independent proof in this case to have warranted conviction had the confession been extra-judicial. See also text at and following note 119 supra. 


\section{Significance of the Jury Charge}

It is not clear from the decisions whether the corpus delicti rule requires merely that there be a certain quantum of independent evidence of the corpus delicti in the record, or whether the jury's verdict must be based to some extent on that independent evidence. If the former is true, then the rule is simply a test to be applied by the court, and no charge on this point is necessary. If the latter, then a charge would be imperative, although as a practical matter it would play a significant role in relatively few cases.

A charge to the jury would be unimportant when the extrinsic evidence introduced undoubtedly would convince the jury that a murder had been committed. This would be the case if a defendant confessed to murder and the prosecution produced testimony by witnesses who positively identified the body of the deceased and testimony by the coroner that death was caused by a bullet wound in the back.

A charge could be important when the jury might disbelieve the extrinsic evidence introduced by the prosecution to prove the corpus delicti. An example would be a murder prosecution in which the defendant confessed that, months earlier, he had murdered the deceased by hitting him over the head and throwing the body in a river, and in which there was testimony that a decayed body of the same sex, and approximate in size to the deceased, had been found in the river, that bits of clothing found on the body matched the clothes which the deceased had been wearing on the day he disappeared, and that the wound on the deceased's head might have come from either a blow by a blunt instrument or from contact with rocks in the river. Without instructions that the corpus delicti cannot be proved by the confession alone, the jury might return a verdict based solely on the confession. But even when the jury might be unconvinced by the independent evidence, the effect of proper instructions often would be questionable. This would be especially true where the independent evidence presents a question of credibility, as where the defendant confesses to forcible rape but claims at the trial that the prosecutrix had consented, and the only evidence of criminality other than the confession is the testimony of the prosecutrix. It is possible that the jury originally disbelieved the prosecutrix but was swayed the other way on the question of credibility once the confession had been introduced. Thus a verdict of guilty really would be based on the confession. However, it is doubtful that once the confession had been introduced the jury could answer the question of how they would have decided the issue of credibility had there been no confession.

Wheeler v. Commonwealth ${ }^{134}$ is the only case discovered in which a conviction was reversed because of the trial court's failure to charge the jury that the confession by itself is not sufficient proof of the corpus delicti,

134. 191 Va. 665,66 S.E.2d 605 (1951) ; cf. Winslow v. State, 76 Ala. 42, 47-48 (1884); Coley v. State, 110 Ga. 271, 34 S.E. 845 (1899). 
even though the appellate court found there was sufficient independent evidence in the record. The court was aware of the possibility that the jury might have based its verdict on the confession alone.

In Pennsylvania the jury must find beyond a reasonable doubt that a crime was committed, without considering the confession. ${ }^{135}$ Since the confession has been introduced into evidence before the jury considers its verdict, it is necessary that there be proper instructions. ${ }^{136}$ The practicality of this rule also is doubtful, since it is almost certain that the jury will be influenced by knowledge of the confession.

\section{CORROBORATION}

Some jurisdictions which hold that the defendant's confession is not sufficient for conviction are satisfied with some extrinsic corroboration of the confession, ${ }^{137}$ instead of requiring independent proof of the corpus delicti.

135. See text at note 195 infra. (1928).

136. See Commonwealth v. Danarowicz, 294 Pa. 190, 194, 144 At1. 127, 128

137. Anderson v. United States, 124 F.2d 58 (6th Cir. 1941), rev'd on other grounds, 318 U.S. 350 (1943); W.iggins v. United States, 64 F.2d 950 (9th Cir. 1933); Aplin v. United States, 41 F.2d 495 (9th Cir. 1930); Pearlman v. United States, 10 F.2d 460 (9th Cir. 1926); Martinez v. People, 267 P.2d 654 (Colo. 1954); State v. Cardwell, 90 Kan. 606, 135 Pac. 597 (1913); State v. Geltzeiler, 101 N.J.L. 415, 128 Atl. 240 (1925) ; State v. Banusik, 84 N.J.L. 640, 64 Atl. 994 (1906). Cf. Opper v. United States, 75 Sup. Ct. 158 (1954).

At one time Georgia required corroboration only. Anderson v. State, $72 \mathrm{Ga}$ 98 (1884) ; Green, Evidence, 3 Mercer L. REv. 100-02 (1951). But Bines v. State, $118 \mathrm{Ga} .320,45 \mathrm{~S} . \mathrm{E}$. 376 (1903), held that there must be independent proof of the corpus delicti, misciting Murray v. State, $43 \mathrm{Ga}$. 256 (1871), which merely said that a confession alone cannot support a conviction. Wimberly v. State, $105 \mathrm{Ga}$. 188, 31 S.E. 162 (1898), had held that independent proof of the corpus delicti was sufficient corroboration but did not say that such proof was necessary. Although Holsenbake v. State, $45 \mathrm{Ga} .43,57$ (1872), which says that a confession which is corroborated by only one circumstance is sufficient for conviction, has never been overruled, it has not been cited recently. The Georgia statute states merely that: "a confession alone, uncorroborated by other evidence will not justify a conviction." GA. Code ANn. \$38-420 (1933).

Illinois at one time required only corroboration of any number of the great variety of facts which usually attend or are incidentally connected with the commission of every crime. Bergen v. People, 17 Ill. 426 (1855). But later cases require that this corroboration also tend to prove the corpus delicti. People v. Harrison, 261 IIl. 517, 104 N.E. 259 (1914); People v. Gavurnik, 2 I11.2d 190, 117 N.E.2d 782 (1954).

A statement by an early New York court, in People v. Badgley, 16 Wend. 53, 59 (N.Y. 1836), that: "Full proof of the body of the crime, the corpis delicti, independently of the confession, is not required ..; and in many... [cases] slight corroborating facts were held sufficient," has been cited for the proposition that proof of the corpus delicti independent of the confession is not required at all if there is incidental corroboration. E.g., Daeche v. United States, 250 Fed. 566, 571 (2d Cir. 1918); People v. Bergen, 17 I1l. 426, 429 (1856) ; State v. Banusik, 84 N.J.L. $640,646-47,64$ At1. 994, 996 (1906). But later cases indicate that the rule in New York is that there must be independent proof of the corpus delicti. People v. Deacons, 109 N.Y. 374, 16 N.E. 676 (1888); see People v. Steinmetz, 240 N.Y. 411,148 N.E. 597 (1925) (must have independent proof that the crime was committed, but affirmed since counsel did not make a timely objection).

Judge Learned Hand in Daeche v. United States, 250 Fed. 566, 571 (2d Cir. 1918), stated that: "The corroboration must touch the corpus delicti in the sense 
"A great variety of facts usually attend, or are incidentally connected with, the commission of every crime. Proof of any number of these facts and circumstances, consistent with the truth of the confession, or which the confession has led to the discovery of, and which would not probably have existed had the crime not been committed, necessarily corroborate it, and increase the probability of its truth." 138

Discovery of the deceased's body as a result of the defendant's confessing where he had buried his victim would be sufficient corroboration, although it probably would not be sufficient independent proof of the corpus delicti except in North Dakota. ${ }^{139}$ Since the death was proved, however, it could not be said that there was no evidence of the corpus delicti.

The difference between a jurisdiction which requires slight independent proof which may be used in conjunction with the confession in proving the corpus delicti and a jurisdiction which requires mere corroboration of the confession is mainly one of semantics. Only in rare instances would there be sufficient corroboration to satisfy a corroboration court which would not be sufficient independent proof of the corpus delicti, when added to the confession, to satisfy a court of the other type. Likewise, there would be little practical difference between holding that mere corroboration is sufficient and holding, as does North Dakota, that there must be independent proof of the corpus delicti but that the corpus delicti consists of the death only, since it seems unlikely that a court would consider the corroboration requirement satisfied if there was no proof of the basic injury other than the defendant's confession. ${ }^{140}$

The other jurisdictions requiring proof of the corpus delicti generally require more evidence than would be necessary to satisfy the corroboration theory. Apparently jurisdictions following the corroboration rule have greater confidence in confessions than these other courts. One judge posed the possibility, however, that there might be a situation in which there would be independent proof of the corpus delicti which would not be

of the injury against whose occurrence the law is directed. . . Independently [the corroborating circumstances] . . need not establish the truth of the corpus delicti at all, neither beyond a reasonable doubt nor by a preponderance of proof." Although somewhat ambiguous, this statement apparently means that independent proof of the corpus delicti is required, rather than mere corroboration tending to give confidence in the truth of the confession. Opper v. United States, 75 Sup. Ct. 158, 164 (1954); Forte v. United States, 94 F.2d 236, 241-43 (D.C. Cir. 1937). The latter part of Judge Hand's statement has, however, been quoted as standing for the corroboration rule, rather than proof of the corpus delicti. Pearlman v. United States, 10 F.2d 460, 462 (9th Cir. 1926) ; Wynkoop v. United States, 22 F.2d 799 (9th Cir. 1927). Later Second Circuit opinions clearly follow the rule requiring independent proof of the corpus delicti. See Markman v. United States, 193 F.2d 574 (2d Cir. 1951).

At one time the Fourth Circuit required mere corroboration, Bolland v. United States, 238 Fed. 529 (4th Cir. 1916), but today requires independent proof of the corpus delicti. Bell v. United States, 185 F.2d 302 (4th Cir. 1950), cert. denied, 340 U.S. 930 (1951).

138. Bergen v. People, 17 IIl. 426, 428-29 (1855). But see note 137 supra.

139. See text at notes 64-66 and notes 64-66 supra.

140. But cf. State v. Downing, 23 Idaho 540, 130 Pac. 461 (1913). 
corroborative of the confession ${ }^{141}$ as, for example, where the defendant confesses that he stabbed $X$ to death but discovery of $X$ 's body reveals that death was caused by bullet wounds. Although only a few courts state the requirement of extrinsic evidence in terms expressly indicating that there must be proof of the corpus delicti which is also corroborative of the confession, ${ }^{142}$ if a case such as the one suggested should arise it is extremely doubtful that any court would hold the evidence to be sufficient.

The main problems which exist in jurisdictions which require independent proof of the corpus delicti are minimized in corroboration jurisdictions. It is obviously necessary that the confession be used with the extrinsic evidence in order to determine whether there is corroboration. The courts following the corroboration rule apparently never set down a definite quantum of independent evidence which is required, but rather state the rule in general terms such as "some proof." However, basically the same problem of instructing the jury exists in this type jurisdiction as in a jurisdiction which requires independent evidence of the corpus delicti. Where there is incontrovertible physical evidence corroborating the confession, there is little need for a detailed charge. But where there is contradictory independent evidence, it is important that the jury be instructed to acquit if it disbelieves the prosecution's evidence; for example, where the defendant confesses to arson and one witness testifies that he saw the defendant entering the building in question just before the fire and another witness testifies that the defendant was not near the scene of the fire at that time, the jury should be told that a verdict of guilty cannot be based on the confession alone and that it should acquit if it disbelieves the witness who said that he saw the defendant at the scene of the fire.

\section{EXCEPTIONS TO THE RULE}

\section{0 \\ Judicial Confessions}

There is an abundance of authority for the proposition that a judicial confession is sufficient to support conviction even though unaccompanied by any other evidence. ${ }^{143}$ In Skaggs $v$. State ${ }^{144}$ the prosecutrix reported to a justice of the peace that she had been raped. She took an officer into the park and showed him where two pairs of footprints, one matching the prosecutrix's feet and the other matching the defendant's, led off into the opinion).

141. State v. Johnson, 95 Utah 572, 589, 83 P.2d 1010, 1018 (1938) (dissenting

142. People v. Gavurnik, 2 I11.2d 190, 194, 117 N.E.2d 782, 785 (1954) ; State v. Morro, 313 Mo. 98, 108, 281 S.W. 720,722 (1926); State v. Knapp, 70 Ohio St. $380,393,71$ N.E. 705,707 (1904).

143. E.g., cases cited in notes 144, 145 infra; accord, People v. Manske, 399 Ill. 176, 186, 77 N.E.2d 164, 169 (1948) ; see State v. Cowan, 29 N.C. 239, 244 (1847); State v. Maranda, 94 Ohio St. 364, 371, 114 N.E. 1038, 1040 (1916) ; State v. Johnson, 95 Utah 572, 583, 83 P.2d 1010, 1016 (1938). But of. N.D. REv. CoDE § 12-2729 (1943), to the effect that in prosecutions for murder, manslaughter, or aiding suicide, upon a plea of not guilty, the confession of the accused shall not be admissible to prove the death of the person alleged to have been killed.

144. 88 Ark. 62, 113 S.W. 346 (1908). 
woods where there were signs of a struggle. Prosecutrix's undergarment was torn, and witnesses claimed that they had seen the defendant and prosecutrix together in the park. Defendant was arrested and confessed to the charge of rape at a hearing before a magistrate. While awaiting trial, the defendant was visited four times by the prosecutrix. At trial both defendant and the prosecutrix retracted the previous statements and denied having had intercourse. They claimed that the defendant was the "Lord of Lords" and the "Host of Hosts," that he wanted to be hanged so that he could be resurrected in three days, and that together they had simulated a rape to achieve this end. Prosecutrix claimed she had been raped spiritually but not physically. Defendant asserted that, while awaiting trial, he had learned that he might receive a prison sentence instead of being executed, and that therefore he and the prosecutrix withdrew their original story. Conviction of rape was affirmed on the ground that a judicial confession is sufficient by itself to support conviction. There was a dissenting opinion in which it was pointed out that, although a judicial confession by itself is not insufficient as a matter of law, neither is it sufficient as a matter of law, and that in the instant case, even taking the confession into consideration, there was not sufficient evidence of the corpus delicti. In State $v$. Lamb ${ }^{145}$ the Missouri court affirmed a conviction of murder in the first degree, although no body was found, on the basis of a detailed confession by the defendant in the magistrate's court.

There is some disagreement as to what constitutes a judicial confession. Certainly a confession made at the trial in the form of testimony is a judicial confession. ${ }^{146}$ A confession given in magistrate's court has been held to be judicial, ${ }^{147}$ although one court has said that since the defendant had a right of appeal from the magistrate's court he could not be convicted on his testimony in that court without other evidence. ${ }^{148}$ A confession at a coroner's inquest has been held to be merely quasi-judicial and, therefore, governed by the rules which apply to extra-judicial confessions. ${ }^{149}$ It is not clear whether a plea of guilty at a former trial is even admissible in evidence. ${ }^{150}$ In Kercheval v. United States ${ }^{151}$ the Supreme Court held that use of a former plea as evidence would conflict with permission to withdraw that plea and that therefore it was inadmissible. The New York ${ }^{152}$ and Connecticut ${ }^{153}$ courts, however, have held that a former plea of guilty is

145. 28 Mo. 218 (1859); see discussion of this case in note 133 supra.

146. Iowa Code Ans. \$782.7 (1946); Ky. Cones, CrIm. Prac. $\$ 240$ (1948); Ercoli v. United States, 131 F.2d 354 (D.C. Cir. 1942) ; see State v. Abrams, 131 Iowa 479, 482, 108 N.W. 1041, 1042 (1906); State v. Lamb, 28 Mo. 218, 230 (1859); People v. Hennessey, 15 Wend. 148, 153 (N.Y. 1836).

147. Skaggs v. State, 88 Ark. 62, 113 S.W. 346 (1908); see State v. Lamb, 28 Mo. 218, 230 (1859).

148. Jenkins v. State, 98 Miss. 717, 54 So. 158 (1911).

149. Ezell v. State, 217 Ark. 94, 229 S.W.2d 32 (1950).

150. See Morgan, Basic Problems of Evidence 247-48 (1954).

151. 274 U.S. 220 (1927).

152. People v. Steinmetz, 240 N.Y. 411,148 N.E. 597 (1925).

153. State v. Carta, 90 Conn. 79, 96 At1. 411 (1915). 
admissible but, like an extra-judicial confession, must be supported by independent evidence of the corpus delicti.

The reasoning behind the limitation on the requirement of independent proof of the corpus delicti has been stated to be that the solemnity of formal judicial proceedings, the deliberateness of the occasion, the advice of counsel, and the guidance of the presiding judge will cure, or at least lessen greatly, the dangers inherent in a conviction based solely on the extrajudicial confession of the accused. ${ }^{154}$ Courts are generally less suspicious of confessions made in their presence, and there is no danger of misreporting. ${ }^{155}$ The Iowa Supreme Court indicated that a confession before a committing magistrate was not a judicial confession since the procedure in the Iowa magistrates' courts lacks the requisite formality. ${ }^{156}$ Another court held that the defendant's confession before a magistrate was not judicial since he was not represented by counsel. ${ }^{157}$

However, it should be recognized that many of the dangers present in extra-judicial confessions ${ }^{158}$ remain in judicial confessions. Certain police methods are so efficient that their influence extends into the court room. In a case in which the police played on the defendant's fear of the lynch mob, the defendant was so frightened that he desired conviction in order to be safe in prison. ${ }^{159}$ A false judicial confession in that case was almost as possible as an extra-judicial one. It is possible for a defendant to have been so intimidated by a police beating that he will confess falsely in court. ${ }^{160}$ And certainly where a psychological problem is involved there is almost as much danger of a false confession in the courtroom as out of it. Where an innocent defendant is faced with overwhelming circumstantial evidence of guilt, he might confess in court in order to receive a mitigated sentence. ${ }^{161}$ The courts seem to overestimate the value of a judicial, as contrasted with an extra-judicial, confession. Perhaps the reason is that they have less emotional distrust of a confession made before them. Certainly the distrust would be greater where the defendant has repudiated his confession before trial.

\section{Admissions and Exculpatory Statements}

Statements by the accused pertaining to his participation in the crime may be classified into three main groups: (1) Confessions-conscious acknowledgments of guilt of the crime with which the defendant is charged;

154. State v. Lamb, 28 Mo. 218, 230 (1859).

155. Compare text at note 29 and note 29 supra.

156. State v. Abrams, 131 Iowa 479, 108 N.W. 1041 (1906). 1947).

157. Commonwealth v. Banks, 58 Dauph. Co. Rep. 134 (Pa., Ct. Oyer \& Ter.

158. See text at and following note 27 supra.

159. Case of John A. Johnson (Wisconsin, 1911), in BorCEARd, ConVICTING THE INNOCENT 112 (1932). (1951).

160. E.g., Commonwealth ex rel. Sheeler v. Burke, $367 \mathrm{~Pa} .152,79$ A.2d 654

161. See text at note 33 and note 33 supra. 
(2) Admissions--disclosures of any of the material facts of the crime short of an acknowledgment of guilt; and (3) Exculpatory Statements-statements that explain the defendant's actions rather than admit guilt. ${ }^{162}$ Some courts require independent proof of the corpus delicti only when the defendant's statements amount to a confession; ${ }^{163}$ other courts apply the rule to confessions and admissions but not to exculpatory statements; ${ }^{164}$ while still other courts apply the rule to all three types of statements. ${ }^{165}$

An analogous problem exists in the application of the rule excluding involuntary statements by the accused. ${ }^{166}$ Some courts exclude only confessions of guilt; ${ }^{107}$ others bar both confessions and admissions. ${ }^{108}$ Since the rule requiring independent proof of the corpus delicti is based to some extent on the belief that the rule excluding involuntary statements fails to protect defendants completely, it is significant to note that Arizona ${ }^{169}$

162. 2 Wharton, Crminal Evidence $\$ 579-81$ (11th ed. 1935).

163. People v. Manske, 399 Ill. 176, 77 N.E.2d 164 (1948) (conviction of manslaughter affirmed; defendant made statement that he had hit deceased twice, knocking her down); People v. Creedon, 281 N.Y. 413, 24 N.E.2d 105 (1939) (conviction of driving truck for longer period than permitted by statute affirmed; defendant had kept record of the trip); cf. Commonwealth v. Price, 67 York Leg. Rec. 21, 22 (York County, Pa., Q.S. 1953) (conviction of drunken driving affirmed; defendant admitted the car involved in the accident was his, from which fact it was concluded that he had been driving); see Reid v. State, $168 \mathrm{Ala}$. 118, 122, 53 So. 254, 255 (1910); State v. Weston, 102 Ore. 102, 115, 201 Pac. 1083, 1088 (1921).

164. Opper v. United States, 211 F.2d 719, 722 (6th Cir.), aff'd on other grounds, 75 Sup. Ct. 158 (1954); Ercoli v. United States, 131 F.2d 354 (D.C. Cir. 1942); see Braxton v. State, 17 Ala. App. 167, 169, 82 So. 657, 659 (1919). Wigmore favors this view. 3 WIGMORE, EVIDENCE $\$ 821$ (3d ed. 1940).

165. State v. Abrams, 131 Iowa 479, 108 N.W. 1041 (1906) (conviction of carrying a concealed weapon reversed; defendant admitted carrying the weapon but claimed a right to do so) ; see Opper v. United States, 75 Sup. Ct. 158, 164 (1954); State v. Romo, 66 Ariz. 174, 185 P.2d 757 (1947) (conviction of rape affirmed; the court said defendant's admission of having intercourse with prosecutrix with her consent was not sufficient by itself, but there was independent proof); cf. Smith v. United States, 75 Sup. Ct. 194 (1954) ; People v. Villanueva, 74 Cal. App. 276, 240 Pac. 43 (1925) (conviction of alien carrying a firearm reversed; only evidence of defendant's being an alien was his admission); People v. Gonzales, 74 Cal. App. 341, 240 Pac. 291 (1925) (same facts); State v. Jones, 108 A.2d 261 (Me. 1954); State v. Carleton, 148 Me. 237, 92 A.2d 327 (1952); Choate v. State, 12 Okla. Cr. 560, 160 Pac. 34 (1916); Gulotta v. United States, 113 F.2d 683 (8th Cir. 1940).

Iowa and Kentucky courts have reached opposite results on this point in interpreting the statutes in their respective jurisdictions, the wording of which is almost identical. The Kentucky Court of Appeals maintained that the statute says "confession," and, therefore, it applies only to confessions. Hedger v. Commonwealth, $294 \mathrm{Ky} .731,172$ S.W.2d 560 (1943), interpreting, Ky. CoDEs, CrRA. PrAC. $\$ 240$ (1948). However, the Iowa Supreme Court, interpreting IowA CoDE ANN. $\$ 782.7$ (1946), said: "The admission of the fact by the defendant tends to establish it by his confession." State v. Dubois, 54 Iowa 363, 365, 6 N.W. 578 (1880).

166. See 2 Morgan, Basic Problems of Evidence 296-99 (1954).

167. See cases cited in notes 169,170 infra.

168. See cases cited in notes 171, 172 infra; cf. Ashcraft v. Tennessee, 327 U.S. 274 (1946) (where the admission for all practical purposes amounts to a confession of guilt).

169. Lawrence v. State, 29 Ariz. 247, 240 Pac. 863 (1925), cert. denied, 269 U.S. 585 (1926) (the rule as to voluntary statements does not apply to admissions); see State v. Romo, 66 Ariz. 174, 187, 185 P.2d 757, 765 (1947) (corpus delicti rule applies to admissions as well as to confessions). 
and California ${ }^{170}$ do not exclude involuntary admissions but do require that the corpus delicti be proved by evidence independent of such admissions; on the other hand, Alabama ${ }^{171}$ and Illinois ${ }^{172}$ prohibit the introduction of involuntary admissions as well as confessions, but do not require independent proof of the corpus delicti in the case of admissions.

Although the Georgia Court of Appeals held that an exculpatory statement did not come within the rule requiring independent proof of the corpus delicti, it indicated that an exculpatory statement, by its nature, would never in itself present sufficient proof that a crime had been committed.173 In that case unidentifiable remains were found, and the defendant admitted killing the deceased but asserted that the killing was in self-defense. The trial court charged the jury that it was entitled to believe the defendant's statement in part and to disbelieve it in part, and that proof of homicide raises a presumption of malice sufficient to warrant a verdict of second degree murder. The jury returned a verdict of murder in the second degree, although there was no independent evidence that the killing was felonious. The appellate court reversed, stating that: "If the main fact is admitted, with a qualifying exclusion of a necessary ingredient of the crime charged, the crime is not confessed. The qualification is a part of the admission, and both must be considered in interpreting the meaning of the statement." 174 The Supreme Court of Missouri in a prosecution for attempted robbery ${ }^{175}$ reached an illogical conclusion as to what constitutes a confession. The defense was insanity, and evidence of statements by the defendant that he had committed other robberies was admitted by the lower court as relevant to the mental condition of the defendant in committing these robberies. The Supreme Court reversed, holding that, as proof that the defendant had committed the other crimes, the statements were extrajudicial confessions and were not admissible without other proof of the corpus delicti of the crimes to which the defendant had confessed.

\section{Statements Which Are Part of the Res Gestae}

Some courts have held that independent proof of the corpus delicti is unnecessary when the defendant's confession is admissible as part of the

170. People v. Johnson, 203 Cal. 153, 263 Pac. 524 (1928) (rule that an involuntary statement is not admissible does not apply to admissions, however harmful they may prove to be); People v. Villanueva, 74 Cal. App. 276, 240 Pac. 43 (1925) (corpus delicti rule applies to admissions as well as to confessions); People v. Gonzales, 74 Cal. App. 341, 240 Pac. 291 (1925).

171. Watts v. State, 177 Ala. 24, 59 So. 270 (1912) semble; Morris v. State, 25 Ala. App. 156, 161, 142 So. 592, 596, rev'd on other grounds, 25 Ala. App. 162, 142 So. 597 (1932) (admissions must be voluntary to be admissible); see Reid v. State, 168 Ala. 118, 53 So. 254 (1910) (corpus delicti rule does not apply to admissions).

172. See People v. Colvin, 294 III. 196, 128 N.E. 396 (1920) (involuntary admissions are not admissible); People v. Manske, 399 Ill. 176, 77 N.E.2d 164 (1948) (corpus delicti rule does not apply to admissions).

173. Wall v. State, 5 Ga. App. 305, 63 S.E. 27 (1908).

174. Id. at 308,63 S.E. at 28.

175. State v. Flores, 332 Mo. 74, 55 S.W.2d 953 (1932). But cf. Bahn v. Commonwealth, 92 Pittsb. Leg. J. 375 (Pa., Ct. Oyer \& Ter. 1942). 
res gestae. ${ }^{176}$ In Commonzealth $v$. Danarowicz ${ }^{177}$ a letter written by the defendant confessing the murder of his wife was found next to the wife's dead body. The Pennsylvania Supreme Court held that this letter was correctly admitted as part of the res gestae, "a fact connected in time and place with the offense itself," 178 and, therefore, that independent proof of the corpus delicti was not required. In State v. Saltzman ${ }^{179}$ the defendant stopped his car shortly after crossing the state line into Iowa, ran to a telephone, and called the police, telling them that a car was following him and he feared that the liquor which he had in his car was in danger of being hijacked. While the defendant was telephoning, the car which had been following him pushed his car away. There was no independent evidence that the defendant's car contained liquor, except the testimony of witnesses that the defendant's car seemed heavily loaded. However, they could not tell what was in the car. The Iowa Supreme Court affirmed a conviction of illegally transporting liquor across the state line, holding that the defendant's confession was admissible as part of the res gestae and no independent proof was required.

The logic behind this exception to the rule seems questionable. An extra-judicial confession is hearsay evidence, but is admissible under the theory that a confession lacks the weaknesses of ordinary hearsay because the defendant cannot be heard to complain that he was deprived of the right to cross-examine himself or that his own statements were not under oath. ${ }^{180}$ Res gestae statements are likewise admissible hearsay under the theory that when a statement is made in the excitement of the moment the declarant probably has not used his mental processes to concoct an untrue story. ${ }^{181}$ These, however, are rules governing the competence of evidence to be admitted. The rule that the prosecution must prove the corpus delicti by evidence independent of the defendant's confession is a rule governing the sufficiency of evidence to convict. It is illogical to hold that, merely because the same class of evidence becomes admissible as part of the res gestae rather than as a confession, the rule as to sufficiency does not apply. ${ }^{182}$

176. State v. Clark, 102 Mont. 432, 58 P.2d 276 (1936) (conviction of gambling affirmed; defendant made statements in card game where chips were being used: "I will bet a dollar .. I am loser a dollar."); Majors v. State, 100 Tex. Crim. Rep. 304,273 S.W. $267^{\circ}$ (1925) (conviction for illegal manufacture of liquor affirmed; defendant made statement upon arrest near the still: "You have got me."); see notes 177, 179 infra.

177. 294 Pa. 190, 144 Atl. 127 (1928).

178. Id. at 194, 144 At1. at 128.

179. 241 Iowa 1373, 44 N.W.2d 24 (1950).

180. Morgan, Admissions as an Exception to the Hearsay Rule, 30 YALE L.J. 355, 361 (1921) ; 4 WigMore, EVIDENCE $\$ \$ 1048,1050$ (3d ed. 1940).

181. 2 Morgan, Basic Problems of Evidence 296-99 (1954).

182. This theory was apparently used by the court in Carr v. State, 21 Ala. App. 299, 109 So. 730 (1926) (statements admissible as part of the res gestae, but not sufficient to convict without independent proof of the corpus delicti); see also State v. Saltzman, 241 Iowa 1373, 1383, 44 N.W.2d 24, 35 (1950) (dissenting opinion). 


\section{Statements Made Before the Commission of the Crime}

In the few cases in which the question has been presented, it has been held that statements made by the defendant before the commission of the crime do not need support of independent proof of the corpus delicti.183 In Warzower $v$. United States ${ }^{184}$ the defendant was prosecuted for entering the United States with a passport which had been secured by false statements as to the defendant's name, citizenship, place of birth, and residence abroad. The Government introduced the manifest of alien passengers of the ship on which the defendant allegedly first came to the United States, his draft registration papers, and an application for re-entry in order to show defendant's statements as to his alleged name, citizenship, place of birth, and residence abroad. The Supreme Court held that, since the statements were made before the commission of the crime, independent proof of the falsity of the statements was not required. The Court said that the purpose of the requirement of independent proof is to prevent conviction on a false confession. "Where the inconsistent statement was made prior to the crime this danger does not exist." ${ }^{185}$ In Commonzealth $v$. Jones ${ }^{186}$ the Pennsylvania Superior Court held statements made by the defendant before the crime that he had insured his building and that someone was going to burn it were admissible in an arson prosecution and were sufficient to convict without independent proof of the corpus delicti.

The greatest dangers of a conviction based solely on the confession of the defendant are eliminated where his statements were made before the commission of the crime. When the statements are removed from the context of the crime which allegedly has been committed, the possibility of a pathological confession is greatly lessened, if not eliminated, and certainly no danger of third degree methods exists.

\section{Misdemeanors}

There is a split in the decisions as to whether the corpus delicti of misdemeanors and lower grade crimes must be proved independently. North Dakota has a unique rule, applying the requirement only to murder, manslaughter, and aiding suicide. ${ }^{187}$ Some courts have held that the rule applies only to felonies, ${ }^{188}$ thus excluding misdemeanors and lesser viola-

183. See notes 184,186 infra.

184. 312 U.S. 342 (1940).

185. Id. at 347 .

186. $97 \mathrm{~Pa}$. Super. 417 (1929).

187. N.D. Rev. Code $\$ 12-2729$ (1943). It would seem that the North Dakota Supreme Court would limit the rule to the specific language of the statute since in State v. Gibson, 69 N.D. 70, 284 N.W. 209 (1938), this section of the statute was interpreted strictly according to its language on another point. See text preceding note 66 supra.

188. Commonwealth v. Quick, 15 Pa. Dist. R. 260 (Monroe County Q.S. 1905); State v. Gilbert, 36 Vt. 145 (1863); see Commonwealth v. Kendrick, 70 Pa. D. \& C. 366,368 (Montgomery County Q.S. 1949); Egbert v. State, 113 Neb. 790, 795, 205 N.W. 252, 254 (1925). 
tions. Other courts have applied the rule to both felonies and misdemeanors. ${ }^{180}$ New York seems to apply the rule to all felonies and misdemeanors, and to offenses which carry the same stigma and penalty as misdemeanors, 190 but not to "infractions." 191

A wrongful conviction certainly is much more shocking to a court when the punishment is execution or long imprisonment than when only a short prison term is involved; but from the point of view of the community the more serious the offense, ordinarily the more important it is that the guilty party not escape conviction. At present, however, the often illogical distinctions drawn by many legislatures between felonies and misdemeanors provide no sound basis for a decision as to whether the corpus delicti rule should be relaxed or eliminated as to a particular class of crimes.

\section{Practical Effects of the Rule}

According to the language of the Pennsylvania decisions, prima facie independent evidence of the corpus delicti must be in the record before the defendant's extra-judicial confession is admitted in evidence. The corpus delicti is sufficiently proved to warrant the introduction of the confession "where the circumstances attending death are consistent with crime, though they also may be consistent with accident . . ., or suicide . . ., and it is not necessary to show by affirmative proof that the latter two possibilities do not exist before evidence as to who did the act is admitted. . . ." 192 Then the jury should be instructed that they must be convinced beyond a reasonable doubt of the existence of the corpus delicti before they can take the defendant's confession into consideration. ${ }^{193}$ The rule was first set

189. Commonwealth v. Allen, 41 Del. Co. 56 (Delaware County, Pa., Oyer \& Ter. 1953); Commonwealth v. Waugh, $56 \mathrm{~Pa} . \mathrm{D}$. \& C. 170 (Montgomery County Q.S. 1946) (court applied the rule to a misdemeanor without discussing the possibility that a misdemeanor might be an exception).

190. People v. Williams, 119 N.Y.S.2d 500 (Spec. Sess. 1953) (conviction of offense of street walking reversed), Contra: People v. Erickson, 171 N.X. Misc. 937,13 N.Y.S.2d 997 (1939), rev'd on other grounds, 283 N.Y. 210,28 N.E.2d 381 (1940).

191. People v. Lowey, Horovits \& Fischer, Inc., 186 N.Y. Misc. 745, 60 N.Y.S.2d 145 (1946).

192. Commonwealth v. Gardner, 282 Pa. 458, 464, 128 Atl. 87, 90 (1925) (no confession involved). The following cases in which confessions were involved quote this language from Gardner with approval: Commonwealth v. Turza, $340 \mathrm{~Pa}$. 128 , 135, 16 A.2d 401, 405 (1940); Commonwealth v. Coontz, $288 \mathrm{~Pa}$. 74, 79, 135 Atl. 538, 539 (1927); Commonwealth v. Bishop, 285 Pa. 49, 53, 131 At1. 657, 659 (1926).

193. Commonwealth v. Bishop, 285 Pa. 49, 131 Atl. 657 (1926); Commonwealth v. Puglise, $276 \mathrm{~Pa}$. 235, 120 Atl. 401 (1923) ; Gray v. Commonwealth, $101 \mathrm{~Pa} .380$ (1882); see Commonwealth v. Danarowicz, $294 \mathrm{~Pa}$. 190, 194, 144 Atl. 127, 128 (1928). Cf. Commonwealth v. Iettrich, $346 \mathrm{~Pa}$. 497, 31 A.2d 155 (1943), in which the court said: "In practice, the rule requires that the jury may not consider such confession as evidence of the defendant's guilt of the crime charged, unless the Commonwealth shall have produced evidence sufficient to convince the jury beyond a reasonable doubt that the crime charged was committed by someone." Id. at 502,31 A.2d at 157 . (Italics added.)

It could be argued that the court was saying that the defendant's confession could be used as cumulative proof of the corpus delicti once prima facie independent proof is introduced, but cannot be used as proof of defendant's agency in the crime until the jury is convinced of the corpus delicti beyond a reasonable doubt. 
forth by the Pennsylvania Supreme Court in 1882 in Gray v. Commonwealth, ${ }^{184}$ a case which remains in full force today.

"The true rule in such cases is believed to be this: when the commonwealth has given sufficient evidence of the corpus delicti to entitle the case to go to the jury, it is competent to show a confession made by the prisoner connecting him with the crime. Under such circumstances the jury should first pass upon the sufficiency of the evidence of the corpus delicti. If it satisfies them beyond a reasonable doubt that the crime has been committed, then they are at liberty to give the confession such weight as it is entitled to, taking into view the circumstances surrounding it, and the extent to which it has been corroborated." 195

Undoubtedly a number of cases in which there is either no independent evidence or very slight independent evidence of the corpus delicti are disposed of at the police level, and, thus, never brought to trial. Also a number of these cases undoubtedly result in verdicts for the defendant at trial. However, in Pennsylvania, which has adopted the most stringent form of the rule, the practical effect on the outcome of the reported appellate cases has not been very marked. Of these twenty cases, fifteen were affirmed on their merits, ${ }^{196}$ two were affirmed because they fell within an exception to the rule, ${ }^{197}$ and only three cases were reversed..$^{198}$

There was virtually no independent evidence of the corpus delicti in one of the reversed cases and no evidence of the criminality element of the corpus delicti in the other two cases. Thus, the fact that Pennsylvania imposes a stringent requirement has been of little consequence to date. The facts of the three cases that were reversed are: (1) Conviction of larceny and receiving stolen goods reversed. The manager of the store from which defendant confessed that he had stolen the goods testified that the goods were of the type which he sold, that they "could" have come from his store, and that he could not say whether or not these articles had been

194. 101 Pa. 380 (1882).

195. Id. at 386.

196. Commonwealth v. Lettrich, 346 Pa. 497, 31 A.2d 155 (1943); Commonwealth v. Turza, $340 \mathrm{~Pa}$ 128, 16 A.2d 401 (1940); Commonwealth v. Jones, 297 Pa 326, 146 Atl. 905 (1929); Commonwealth v. Coontz, 288 Pa. 74, 135 At1. 538 (1927); Commonwealth v. Marsha11, 287 Pa. 512, 135 Atl. 301 (1926) ; Commonwealth v. Bishop, $285 \mathrm{~Pa}$. 49, 131 At1. 657 (1926); Gray v. Commonwealth, $101 \mathrm{~Pa}$. 380 (1882) ; Commonwealth v. Du Hadway, 175 Pa. Super. 201, 103 A.2d 489 (1954); Commonwealth v. Adams, $174 \mathrm{~Pa}$. Super. 504, 102 A.2d 202 (1954); Commonwealth v. Young, $172 \mathrm{~Pa}$. Super. 102, 92 A.2d 445 (1952); Commonwealth v. Dolph, 164 $\mathrm{Pa}$. Super. 415, 65 A.2d 253 (1949); Commonwealth v. Ferguson, $162 \mathrm{~Pa}$. Super. 199 , 56 A.2d 360 (1948); Commonwealth v. Amato, 148 Pa. Super. 151, 24 A.2d 681 (1942); Commonwealth v. Chuing, 150 Pa. Super. 445, 28 A.2d 710 (1942); Commonwealth v. Kaufman, $94 \mathrm{~Pa}$. Super. 419 (1928).

197. Commonwealth v. Danarowicz, 294 Pa. 190, 144 Atl. 127 (1928); Commonwealth v. Jones, $97 \mathrm{~Pa}$. Super. 417 (1929).

198. See cases cited in notes 199-201 infra. 
purchased. ${ }^{199}$ (2) Conviction of murder in the first degree, reversed. The deceased was found hanging from a tree. An expert witness testified that in his opinion it was suicide. Therefore, not only was there a lack of evidence of criminality but there was affirmative evidence of suicide. ${ }^{200}$ Conviction of arson reversed. There was no evidence of criminality other than the confession. ${ }^{201}$

In at least three of the fifteen cases which the Pennsylvania courts have affirmed on their merits there is a serious question as to whether there was sufficient proof of the corpus delicti aliunde the defendant's confession to warrant conviction, thus leaving some doubt as to whether the courts require as much evidence as they claim. The facts of these three cases are: (1) Murder in the first degree affirmed. The deceased was found in the highway, and a wound on his head was as consistent with an accident as with crime. ${ }^{202}$ (2) Murder in the first degree affirmed. The body of the allegedly murdered infant was never found. The defendant, who was the deceased's mother, had made false declarations and actions in regard to the child's disappearance. This was the only evidence other than defendant's confession. ${ }^{203}$ (3) Conviction of sodomy affirmed. The only evidence was the confessions of the defendant and the girl within each other's presence. ${ }^{204}$

\section{Conclusion}

The most persuasive factor in favor of the requirement of independent proof of the corpus delicti is the danger that a false confession was made either because of third degree methods by the police or because of the mental derangement of the defendant, against both of which the rules excluding involuntary confessions afford inadequate protection to the defendant. The shocked consciences of the courts upon finding that defendants have been convicted and executed solely on the basis of their confessions when the persons whom they supposedly have murdered were not in fact dead, and the hesitancy of the courts to convict defendants solely on their own statements, are more historical explanations of why the rule evolved than reasons for continuing its existence. The other factors, although not sufficient in themselves to support the rule, are helpful in determining the scope to be given to the rule in particular factual situations.

Although the present rule requires independent proof of only the first two elements of the crime, some of the factors underlying the corpus delicti rule would provide as much reason for applying the rule to the third element as to the first two. A value judgment is required to determine whether society is best served by protecting the few innocent men who would be wrongly convicted in the absence of a rule covering all three ele-

199. Commonwealth v. Gold, 155 Pa. Super. 364, 38 A.2d 486 (1944).

200. Commonwealth v. Puglise, $276 \mathrm{~Pa}$. 235, 120 At1. 401 (1923).

201. Commonwealth v. Winter, $174 \mathrm{~Pa}$. Super. 35, 98 A.2d 221 (1953).

202. Commonwealth v. Turza, $340 \mathrm{~Pa}$. 128,16 A.2d 401 (1940).

203. Commonwealth v. Lettrich, $346 \mathrm{~Pa}$. 497, 31 A.2d 155 (1943).

204. Commonwealth v. Young, 172 Pa. Super. 102, 92 A.2d 445 (1952). 
ments, or by preventing the indeterminable number of guilty men from escaping conviction because the prosecution has no evidence, except their confessions, of their participation in the crime.

Although the courts have held consistently that reversal of the normal order of proving the corpus delicti independently before the introduction of the confession is in the sound discretion of the trial court, it seems that they have overlooked the possible prejudice to the defendant which might result. A confession might very possibly color the jury's thinking on certain issues which it might otherwise have been able to decide objectively.

Where there is contradictory evidence as to the corpus delicti, it is very important that the jury receive carefully-worded instructions explaining that its verdict cannot rest solely on the defendant's confession. The jury must be cautioned against allowing the confession to prejudice its thinking in relation to the independent evidence of the corpus delicti. However, the importance of instructions is minimized if the prosecution has presented incontrovertible physical evidence that a crime was committed.

In determining whether the corpus delicti rule should apply to a particular case, the courts should examine the rationales and solve the problem in the light of the reasons behind the rule. And if the rule does apply, the most important thing for the courts to keep in mind is that the rule is not a set formula which can be applied to the same extent in every factual situation. 